\title{
Effect of pH and light on aggregation and conformation of an IgG1 mAb
}

\begin{abstract}
BY
Bruce D. Mason

Submitted to the graduate degree program in Pharmaceutical Chemistry and the Graduate Faculty of the University of Kansas in partial fulfillment of the requirements for the degree of Master of Science.
\end{abstract}

Chairperson Dr. Christian Schöneich

Dr. Bruce A. Kerwin

Dr. David Volkin

Date Defended: May 31, 2011 
The Thesis Committee for Bruce D. Mason

certifies that this is the approved version of the following thesis:

\section{Effect of pH and light on aggregation and conformation of an IgG1 mAb}

Chairperson Dr. Christian Schöneich

Date approved: May 31, 2011 


\section{Abstract:}

During the purification process, monoclonal antibodies may be exposed to parts of UV-C (200 to $290 \mathrm{~nm}$ ), UV-B (290 to $320 \mathrm{~nm}$ ) and visible light (400 to $760 \mathrm{~nm}$ ) under a variety of buffer and pH conditions. Together, these conditions can promote both chemical and physical degradation which may result in conformational changes. To examine this possibility, the impact of UV light on an IgG1 mAb at pH 3.5, 5 and 8 was studied at multiple protein concentrations. Exposure to $302 \mathrm{~nm}$ light resulted in a pH-dependent formation of high molecular weight species where the degree of oligomerization increased with increasing $\mathrm{pH}$. Characterization by SDS-PAGE under reducing and non-reducing conditions, and SEC-MALS, revealed that the predominant species were non-reducible dimeric, trimeric and higher order oligomeric species which occurred through processes other than intermolecular disulfide bond formation. Biophysical characterization by differential scanning calorimetry demonstrated an overall loss of heat capacity suggesting a loss of conformational integrity with light exposure. A decrease in tryptophan fluorescence was paralleled by a significant decrease in the transition temperature measured during heat-induced unfolding following light exposure also suggesting a significant change in conformational integrity. The observations by fluorescence spectroscopy coincided with $\mathrm{pH}$ dependent changes in the alterations of secondary structure characterized by Fourier transform infrared spectroscopy and far UV circular dichroism with the most acidic $\mathrm{pH}$ showing the greatest degree of change in the $\beta$-sheet structure. Exposure to UV light resulted in aggregation with $\mathrm{pH}$-dependent yields decreasing in the following order, 8.0 $>5.0>3.5$, while the opposite trend was observed for conformational changes, with $\mathrm{pH}$-dependent extents decreasing in the following order:3.5>5.0>8.0. These $\mathrm{pH}$-dependent trends suggest that different strategies will be required to stabilize the protein against these modifications during processing. 


\section{Introduction:}

During the protein purification process, antibody products may be exposed to various types of light which are known to degrade proteins. ${ }^{1}$ Chromatographic purification steps typically use detectors that monitor elution of the antibody at both $280 \mathrm{~nm}$ and $300 \mathrm{~nm} .^{2,3}$ In between purification steps, the antibody may be held in large stainless steel or plastic containers that may not be protected from light and, therefore, exposed to ambient fluorescent lighting for up to one day. ${ }^{1}$ In fact, it has been shown that typical commercially available fluorescent tube lights emit UV light of wavelengths as short as $254 \mathrm{~nm}$ in appreciable amounts ranging approximately from $10^{-10}$ to $10^{-5} \mathrm{~W} / \mathrm{cm}^{2} / \mathrm{nm}$. ${ }^{4,5}$ While this amount of exposure is low, on the order of $8.7 \times 10^{-4}$ to $87 \mathrm{~J} / \mathrm{cm}^{2}$ at $302 \mathrm{~nm}$ for an 8 hour day, it still means that antibodies are generally exposed to parts of UV-C (200 to 290nm), UV-B (290 to 320nm) and visible light (400 to $760 \mathrm{~nm}$ ) during the purification process. Additionally, at various stages of purification, the antibody experiences a variety of buffers and buffer conditions ranging from $\mathrm{pH}$ 3-8. ${ }^{6-8}$

\section{Protein degradation pathways}

The characteristics of the native protein’s primary, secondary, tertiary, and quaternary structure help determine a protein's ability to degrade. ${ }^{9}$ Protein degradation can result from a large number of environmental factors such as temperature, light, the presence of oxidizing agents, and $\mathrm{pH}^{10}$ A number of additional stresses can also result in protein degradation. These stresses include freeze-thaw, shaking, shear stress, as well as liquid-surface and liquid-air interfaces. ${ }^{9,11}$

There are two pathways that proteins can degrade; chemical and physical. ${ }^{11-14}$ Chemical degradation of proteins can proceed via a number of reactions. Hydrolysis involves either the cleavage of peptide bonds or deamidation of asparagines and glutamine residues. ${ }^{15,16}$ Oxidation of the side chains of histidine, methionine ${ }^{12}$, cysteine, tryptophan and tyrosine residues may 
occur. ${ }^{15}$ These residues, as well as the peptide backbone, ${ }^{11}$ may also be susceptible to photooxidation. ${ }^{11,15}$ Additional chemical degradation may take the form of incorrect disulfide formation/shuffling, racemization, and pyroglutamic acid formation. ${ }^{11,15-17}$ Cysteine, serines, threonine, phenylalanine and lysine residues can also undergo $\beta$-elimination under alkaline conditions. $^{15,16}$

Physical instability of proteins can be caused by a change in the protein's conformation which plays an important role in the therapeutic action of the protein. ${ }^{10,14}$ Denaturation or the unfolding of a protein, resulting in changes in the protein's tertiary or secondary structure have been observed under a variety of conditions ranging from changes in temperature, $\mathrm{pH}$, buffer, physical agitation, or the addition of organic solvents or other denaturants. ${ }^{17}$ Denaturation may be either reversible or irreversible. ${ }^{15}$ Aggregation is still another major source of protein physical degradation and involves the assembly of either covalently or non-covalently linked protein molecules. ${ }^{11}$ Aggregation may proceed via a number of mechanisms. ${ }^{18}$ Reversible self association of monomers in native conformation is one such mechanism. ${ }^{18}$ Aggregation may also occur when there is a change in conformation or unfolding of the native protein which allows for two or more protein molecules to associate. ${ }^{14}$ Taking this mechanism one step further, the change in conformation may be the result of chemical modifications of the protein. Once an aggregate is formed, it can form the nucleus for further aggregation. ${ }^{18}$ As mentioned above, the disulfide structure may be altered forming intermolecular disulfide bonds. ${ }^{14}$ Surface adsorption of therapeutic proteins resulting in loss of protein is classified as a physical instability and may also lead to aggregation. ${ }^{14-16,18,19}$ Complicating matters is that often chemical degradation goes hand in hand with physical degradation. Physical degradation in the form of denaturation may 
lead to chemical degradation, or chemical degradation may result in conformational changes and or aggregation. ${ }^{17}$

\section{Immunogenicity of proteins}

The topic of protein degradation takes on added importance because of the increased potential for an immunogenic response in patients upon administration of protein therapeutics, even for self proteins (autologous proteins). Immunogenicity occurs when a substance is able to

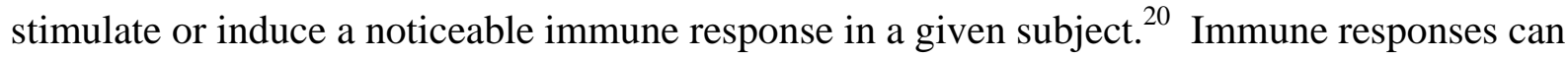
range from simply neutralizing the desired therapeutic action for the protein to anaphylactic shock and patient fatality. ${ }^{21}$ More specifically, immune responses to protein therapeutics can take several different forms ranging from acute infusion or injection site reactions that are anaphylactic or pseudo-allergic/analphylactoid, serum sickness, and effects corresponding to the formation of antibodies against the protein therapeutic that in turn attack endogenous proteins. ${ }^{9}$

Immune responses to foreign proteins (exogenous proteins), commonly referred to as "the classical immune response” occurs through a T-cell dependent pathway. ${ }^{9}$ Here, the targeted protein is captured by antigen-presenting cells (APCs) and digested producing peptides referred to as T-cell epitopes which are then presented as major histocompatibility complex (MHC) Class II molecules on the cell's surface. ${ }^{9}$ These peptides are then recognized by T cells and subsequently activate B cells which generate antibody secreting plasma B cells, both long and short lived. In the process, some of the B cells become memory cells, which maintain a number of long term plasma cells and allow for a rapid immune response should the host be rechallenged with the foreign protein. ${ }^{9}$ The other process by which an immune response may be triggered is the $\mathrm{T}$ cell independent pathway. In this case the targeted protein or antigen is encased by specialized bloodbourne peripheral dendritic cells, which then make their way to the host's 
spleen. At the spleen, the antigen is presented to B cells. This pathway has been used to describe the immune response for particulate antigens typically bacterial or viral in origin and for aggregates in biotherapeutics. ${ }^{9}$

Unfortunately, no specific property of proteins can be used to predict whether a particular protein will trigger an immune response or not. ${ }^{9}$ The complexity of immunogenicity arises from the large number of factors that can play a role in triggering an immune response. These factors can be separated into two categories. The first being related to the patient and include: genetics, any disease state(s), medications and treatment regimen. The second being associated with product related factors classified as CMC-related factors such as the primary sequence and design of the protein, manufacturing process, formulation, container, and stability. ${ }^{9}$ Among the CMC-related factors is the exposure to light during manufacturing. ${ }^{9}$

Protein chemical degradation pathways that can produce an immune response in patients, include: deamidation, deimination, glycosylation, hydroxylation, isomerization, methylation, and phosphorylation. ${ }^{9}$ Of these, only deamidation and oxidation are typically seen in vitro and neither have been documented in the clinic as the direct cause of an immune response. ${ }^{9}$ Despite this, protein oxidation remains a primary concern ${ }^{9}$ with the immunogenicity of the protein in question being highly dependent upon the nature of that protein and the particular residues that have become oxidized. ${ }^{20}$ Protein conformation ${ }^{10}$ and aggregation have both been cited as leading causes for protein therapeutics to be immunogenic. ${ }^{9,20-22}$ Aggregation of proteins, either native, partially, or completely unfolded can potentially lead to an immune response. ${ }^{9}$ Therefore, changes in protein conformation such as those caused by chemical modifications can still play a significant role in eliciting an immune response. ${ }^{21}$ Additionally, proteins experience a great number of stresses that can lead to aggregation during the manufacturing, purification, 
formulation, and packaging steps. A brief list of these factors include: $\mathrm{pH}$, temperature, concentration, ionic strength, freeze-thaw stress, shear stress, interfacial stresses at the liquid surfaces, and mechanical stresses. ${ }^{9,21}$ Different stresses may produce different size distributions and types of aggregates and may even contain different secondary and tertiary structures potentially causing different immune responses in patients. ${ }^{21}$

\section{Chemistry of photooxidation}

The photo-oxidation of proteins proceeds via type I or type II photoprocesses. ${ }^{23,24}$ Type I photooxidation proceeds via singlet or triplet excited states of amino acids, or via photoionization. ${ }^{25}$ Type II photooxidation involves intermediary singlet oxygen $\left({ }^{1} \mathrm{O}_{2}\right)^{23,24}$ but is generally considered less efficient for protein amino acid residues. ${ }^{23}$ Direct photo-oxidation of proteins by a Type I process typically occurs at $\lambda \leq 320 \mathrm{~nm}$ and is only significant at $\lambda>320 \mathrm{~nm}$ if the protein contains a bound co-factor or functional group that is able to absorb light at higher wavelengths. ${ }^{24}$ The amino acid residues of tryptophan, tyrosine, phenylalanine and cystine absorb near UV light while all of the remaining amino acids do not absorb significantly at $\lambda$ $>230 \mathrm{~nm}$. Specifically, tryptophan absorbs between 280-305 nm, tyrosine between 260-290 nm, phenylalanine between $240-270 \mathrm{~nm}$, and finally cystine between $250-300 \mathrm{~nm} .{ }^{1}$ The $\mathrm{n}$ to $\pi^{*}$ transition associated with the peptide bond is observed at $180-220 \mathrm{~nm} .{ }^{26}$ Of primary interest to the current paper is the photodegradation of tryptophan and cystine residues. The photodegradation of tryptophan residues has been studied extensively ${ }^{27,28}$ and a number of photoproducts have been characterized, including the fluorescent products $\mathrm{N}$-formylkynurenine and kynurenine. ${ }^{1}$ An important feature of tryptophan photolysis is the potential for photoinduced electron transfer to nearby disulfide bridges ${ }^{1}$ where disulfide reduction leads to a thiolate and a thiyl radical. ${ }^{1}$ Thiyl radicals can form also via direct light-induced homolysis of cystine disulfide 
bonds ${ }^{29-32}$ and a number of reaction products have been characterized for thiyl radical pairs generated in such way ${ }^{1,33-37}$ For completeness, we note that disulfide bonds can also cleave via C-S bond breakage into carbon-centered radicals and perthiyl radicals, but this process appears to prevail for $\beta$-alkyl substituted disulfides such as, for example, penicillamine. ${ }^{30}$ For comparison, the light-induced cleavage of glutathione disulfide led predominantly to thiyl radicals. ${ }^{30}$

It is well documented that radical mediated damage to proteins may lead to a variety of potentially negative consequences such as fragmentation ${ }^{23,38}$, aggregation ${ }^{25,38,39}$, oxidation ${ }^{40-43}$, changes to surface hydrophobicity, conformational changes ${ }^{39}$ and even denaturation. ${ }^{38,39}$ It may also ultimately result in the loss of activity or simply generate new reactive species propagating the radical reactions. ${ }^{44}$ An examination of the photo-stability of monoclonal antibodies (mAbs) under conditions similar to those observed during purification may provide insights as to how best to avoid these negative consequences.

\section{Prior work on protein photodegradation}

A number of studies have examined the photodegradation of monoclonal antibodies under a variety of conditions using broad spectrum light between 300-800 nm..$^{25,38,41-43}$ Common to all of these studies was photodegradation resulting in the oxidation of tryptophan ${ }^{38,43}$ and methionine ${ }^{38,41,42}$ with differences noted in specific regions of each antibody. Qi et al. observed substantial oxidation of light chain Trp94 in the CDR resulting in multiple oxidation products along with secondary oxidation of Met261, Met437 and His294 of the heavy chain. Interestingly, oxidation of Trp94 was accompanied by cyclization and deamidation of Asn93 along with a concurrent loss of bioactivity. ${ }^{38}$ A similar loss of bioactivity with the loss of Trp in the CDR was also observed for an IgG1 mAb by Wei et al. ${ }^{43}$ Methionine oxidation to methionine sulfoxide in the Fc was also noted by Liu et al. ${ }^{42}$ and Lam et al. ${ }^{41}$ for an IgG1 mAb 
and the rhuMAb HER2, respectively. Liu et al. observed oxidation of Met256 and Met432 while studies by Lam et al. demonstrated oxidation initially occurring on Met255 followed by Met431 under extreme conditions. Wei et al. ${ }^{43}$ identified Met255 and Met431 of an IgG1 mAb along with Met34, Met101 and Met361 of the heavy chain. Similar to Qi et al. the studies by Wei et al. only identified a limited number of oxidized Trp residues, Trp54/55 and Trp105, albeit the heavy chains typically contain up to 15 Trp residues.

More recently, studies by Mozziconnacci et al. focused on the photolytic degradation of disulfides of an IgG1 antibody. ${ }^{33}$ In those studies the mAb was photoirradiated with light at 254 $\mathrm{nm}$ rather than the broad spectrum light noted in the previous studies. They identified a series of dithiohemiacetal and thioether cross-links formed following photoirradiation and suggest the involvement of thiyl radicals in the processes. Conceivably, an analogous process could occur following photolysis at $300 \mathrm{~nm}$, as the photoionization of Trp would result in solvated electron formation leading to one electron reduction of disulfides to the thiyl radical and thiolate.

Studies of the physical and conformational effects of photoirradiation on mAbs have been reported on a much more limited basis than the chemical degradation discussed above. Qi et al. ${ }^{38}$ showed that photoirradiation resulted in a $\mathrm{pH}$ dependent increase in yellowing of the $\mathrm{mAb}$ solution with yellow color noted in basic but not acidic conditions. The mechanism of the yellowing was not defined. In the same studies an increase in aggregation occurred in conjunction with increasing photoirradiation at $\mathrm{pH}$ 5.5. The aggregates were nonreducible in nature which would be consistent with some of the mechanisms noted by Mozicconacci et al. ${ }^{33}$ While changes in the fluorescence intensity with increasing photolysis were also noted, no changes in the conformation by either near or FAR-UV CD were discernible. Similar effects of photolysis corresponding to an increase in aggregation were also reported by Maity et al. ${ }^{25}$ for 
four different mAbs in phosphate buffered saline along with changes in the thermal unfolding profiles indicative of conformational change within the mAbs.

Missing from these studies is a systematic analysis of the effects of $\mathrm{pH}$ and protein concentration on the conformation of a mAb following exposure to UV light typically used during the purification process. Therefore, in this manuscript we studied the effect of $\mathrm{pH}$ and protein concentration on the conformational stability of a model IgG1 mAb during light exposure at $302 \mathrm{~nm}$. The stability of the antibody was examined over a 100-fold range of concentrations from $0.1 \mathrm{mg} / \mathrm{mL}$ to $10 \mathrm{mg} / \mathrm{mL}$ as it is only until the final concentration steps where the antibody concentration is increased during the diafiltration step. Here we demonstrate that conformation and aggregation are inversely correlated with $\mathrm{pH}$ in a concentration-dependent manner for aggregation but not conformation. Aggregation resulted in covalent, non-reducible, crosslinks, consistent with some of the crosslinks suggested by Mozzicconacci et al. ${ }^{33}$ with samples at the highest $\mathrm{pH}$ showing the greatest degree of aggregation. The aggregation may also be result of Cys-Lys crosslinks which have been proposed by Vanhooren, et al. ${ }^{45}$ At all pH's examined, photolysis produced a decrease in the heat capacity of the mAb. The conformational change was confirmed by changes in the heat induced denaturation/unfolding profile of Trp with samples irradiated at pH 3.5 showing multiple transitions during the thermal unfolding process. The inverse $\mathrm{pH}$ dependence of the UV light induced conformational change to that of UV light induced aggregation suggests that different strategies will be required to stabilize the protein against these modifications during processing.

\section{Materials and Methods: Materials}

Anti-Streptavidin IgG1 mAb was obtained from Amgen Inc. at a concentration of 38.5 $\mathrm{mg} / \mathrm{ml}$ in $10 \mathrm{mM}$ sodium acetate, $9 \%$ Sucrose (w/v), $\mathrm{pH}$ 5.2. The ferrioxalate actinometry 
experiment used potassium oxalate 99\% (Acros Organics, part \# 424025000), ferric sulfate (MP Biomedicals, LLC, part \# 158042) and 1, 10-phenantholine 99+\% (Acros Organics, part \# 157530250). Novex Tris-Glycine SDS Running Buffer (Invitrogen Life Sciences, part \# LC2675) and Destain I (Teknova, part number D0010) were used for the gel electrophoresis. A Modified Lowry Protein Assay Kit (Pierce, part \# 23240, Lot \# Jl125160) was used to obtain the protein concentration. To determine the extent of free sulfhydryls in the sample, 5,5'-dithiobis(2-nitrobenzoic acid) (DTNB) obtained from Invitrogen (part \# D8451, Lot 532063 ) and Nacetyl-L-cysteine (NAC) from Sigma (part \# A 7250-5G, Lot \# 118K0049) were used.

\section{Data Analysis}

Where specified, the following software packages were used for data analysis: Microsoft Excel 2007, OriginPro version 8.0 (OriginLab Corporation), Sigma Plot version 11.0 (Systat Software, Inc.), Grams/AI version 9.0 R2 (Thermo Fisher Scientific Inc.).

\section{Sample preparation}

Anti-Streptavidin was determined to have a pI of 8.7 (Amgen internal data). Initial work was conducted using solutions at $0.1 \mathrm{mg} / \mathrm{mL}$ anti-streptavidin to minimize protein-protein interactions and to aid in our understanding of the experimental system. The stock antistreptavidin provided was used to prepare solutions at $0.1 \mathrm{mg} / \mathrm{mL}$ in $10 \mathrm{mM}$ sodium acetate, $\mathrm{pH}$ 3.5 and 5.0 by diluting the stock mAb solution into the corresponding buffer. Similarly, solutions were prepared at $0.1 \mathrm{mg} / \mathrm{ml}$ in $10 \mathrm{mM}$ sodium phosphate, $\mathrm{pH}$ 8.0. These samples were exposed to 302nm light for either 30 or 60 minutes and compared to control samples protected from light.

Subsequent experiments examined the higher mAb concentrations of 1.0 and $10 \mathrm{mg} / \mathrm{mL}$ for ease of analysis by biophysical analytical methods and the bulk of the analysis was done 
using these samples. Solutions were prepared at 1.0 and $10 \mathrm{mg} / \mathrm{mL}$ for the three separate buffer solutions, $10 \mathrm{mM}$ sodium acetate $\mathrm{pH} 3.5$ and 5.0, and $10 \mathrm{mM}$ sodium phosphate $\mathrm{pH}$ 8.0. The aliquots of the samples were then exposed to light as described below for $0,1,5,15,30,45$, and 60 minutes.

Aliquots of 400 and $800 \mu \mathrm{l}$ were placed into quartz cuvettes under a UV lamp $10 \mathrm{~cm}$ distant from the lamps (UVPLMS-38 EL Series 3UV Lamp, part number 95-0252-01, serial number 010406-001) emitting $302 \mathrm{~nm}$ light with an intensity of $1.864 \mu \mathrm{W}$ as measured with a Newport Optical Power Meter, model 840 with calibration module 818-ST/UV, Serial number 242. The photon flux incident to the samples was determined as vide infra. The samples were exposed to ultraviolet light for the specified times described above, in a walk-in cold chamber regulated to $2-8^{\circ} \mathrm{C}$. The control solutions of $0.1,1.0$, and $10 \mathrm{mg} / \mathrm{ml}$ anti-streptavidin in either $10 \mathrm{mM}$ sodium acetate, $\mathrm{pH} 3.5$ or 5.0 were kept at $2-8^{\circ} \mathrm{C}$ protected from light. Similarly, control solutions of $0.1,1.0$, and $10 \mathrm{mg} / \mathrm{ml}$ anti-streptavidin in either $10 \mathrm{mM}$ sodium phosphate, $\mathrm{pH} 8.0$ were also kept at $2-8^{\circ} \mathrm{C}$ protected from light. Samples were stored at $2-8^{\circ} \mathrm{C}$ protected from light until analyzed. The $\mathrm{pH}$ of all solutions was measured after exposure using a Thermo Orion $\mathrm{pH}$ meter with a Thermo Micro Combination pH electrode.

\section{Ferrioxalate Actinometry}

Ferrioxalate actinometry ${ }^{46,47}$ was used to determine the photon flux incident on the samples exposed to $302 \mathrm{~nm}$ light by the UV lamp system described above. As applied by Roy,

S. et. al., all solutions were prepared fresh immediately prior to conducting this experiment. ${ }^{39} \mathrm{~A}$ $0.2 \%(\mathrm{w} / \mathrm{v})$ solution of 1,10 -phenanthroline in water was prepared. The actinometer buffer solution was also prepared by dissolving $82 \mathrm{~g}$ of sodium acetate along with $10 \mathrm{~mL}$ of concentrated sulfuric acid into $1 \mathrm{~L}$ of deionized water. An additional solution of $0.2 \mathrm{M}$ ferric 
sulfate containing $55 \mathrm{~mL}$ of concentrated sulfuric acid and $100 \mathrm{~g}$ ferric sulfate $\left(\mathrm{Fe}_{2}\left(\mathrm{SO}_{4}\right)_{3} n \mathrm{H}_{2} \mathrm{O}\right)$ was prepared to a final volume of $1 \mathrm{~L}$ in deionized water. A final solution of 1.2 $\mathrm{M}$ potassium oxalate $\left(\mathrm{K}_{2} \mathrm{C}_{2} \mathrm{O}_{4}\right)$ was also prepared in water. All three solutions were prepared in aluminum foil wrapped bottles. To conduct the experiment, $5 \mathrm{~mL}$ of the ferric sulfate was added to $5 \mathrm{~L}$ of the potassium oxalate solution in a volumetric flask wrapped in aluminum foil. The mixture of ferric sulfate and potassium oxalate in the volumetric flask was then diluted to $100 \mathrm{~mL}$ with deionized water, in the dark to form a $0.02 \mathrm{M}$ potassium ferrioxalate $\left(\mathrm{K}_{3} \mathrm{Fe}\left(\mathrm{C}_{2} \mathrm{O}_{4}\right)_{3}\right)$ solution. Subsequently, $200 \mu \mathrm{L}$ of $10 \mathrm{mM}$ sodium acetate, $\mathrm{pH} 5.0$ was mixed with $200 \mu \mathrm{L}$ of the potassium ferrioxalate solution and placed into a quartz cuvette to be irradiated by $302 \mathrm{~nm}$ light under similar conditions as the sample experienced. Upon irradiation, the reaction is as described in equation 1. After irradiation, the sample was once again mixed and a $200 \mu \mathrm{L}$ aliquot of it was taken and added to $400 \mu \mathrm{L}$ of the 1,10 -phenanathroline solution with $100 \mu \mathrm{L}$ of the actinometer buffer. The final volume was brought to $2 \mathrm{~mL}$ by the addition of $1.3 \mathrm{~mL}$ of deionized water. The absorbance of this solution was measured at $510 \mathrm{~nm}$ allowing for the determination of the molar concentration of the ferrous-phenanthroline complex using an extinction coefficient of $1.11 \times 10^{4} \mathrm{M} \mathrm{cm}^{-1}$ after using the appropriate dilution factor. Using Avogadro's number $\left(6.023 \times 10^{23}\right.$ molecules/M), the number of molecules of the complex could be determined. Once that was accomplished for each of the exposure times in triplicate, a plot of the molecules of the complex versus exposure time could be obtained allowing for the rate of formation (dn/dt) to be determined. Along with the quantum yield of $\Phi(\lambda)=1.24$ at $302 \mathrm{~nm}$ for a $0.02 \mathrm{M}$ ferrioxalate solution, the photon flux was determined using equation 2 where $\mathrm{P}_{\mathrm{a}, \lambda}$ represents the rate of photons absorbed by the system at $\lambda$ (photons $\mathrm{s}^{-1}$ ). 


$$
\mathrm{Fe}^{3+}+\mathrm{C}_{2} \mathrm{O}_{4}{ }^{2-} \stackrel{h v}{\longrightarrow} 2 \mathrm{Fe}^{2+}+2 \mathrm{CO}_{2}
$$

$$
(\mathrm{dn} / \mathrm{dt})=\Phi(\lambda) / \mathrm{P}_{\mathrm{a}, \lambda}
$$

\section{Modified Lowry Protein Assay}

The protein concentration was also determined using the Modified Lowry Protein Assay Kit. A standard curve of known concentrations of anti-streptavidin was prepared according to the kit instructions. $200 \mu \mathrm{l}$ of each standard concentration was aliquoted in triplicate and treated as individual samples along with $200 \mu \mathrm{l}$ of each unknown anti-streptavidin sample. To each sample, $1 \mathrm{ml}$ of Modified Lowry Reagent was added followed by mixing and incubation at room temperature for exactly 10 minutes. After 10 minutes, $100 \mu \mathrm{l}$ of 1x Folin-Ciocalteu Reagent was added to each sample followed by vortexing. All samples were allowed to incubate in the dark at room temperature for 30 minutes at which point the absorbance was measured at $750 \mathrm{~nm}$ against a water blank.

The modified Lowry Protein Assay was used to determine the protein concentration of the $1 \mathrm{mg} / \mathrm{ml}$ anti-streptavidin samples used in the above assays. In all cases, the protein concentration was determined to be $1.04+/-0.05 \mathrm{mg} / \mathrm{mL}$

\section{Size Exclusion HPLC/ Size Exclusion MALS}

Size exclusion HPLC was performed using an Agilent 1100 HPLC with an isocratic flow rate of $0.5 \mathrm{~mL}$ per minute. The mobile phase consisted of 100mM Sodium Phosphate, $250 \mathrm{mM}$ Sodium Chloride, $\mathrm{pH} 6.8$ at $25.0^{\circ} \mathrm{C}$. The column, purchased from Tosohaas, was a TSKgel G3000SWXL, 7.8 mm ID x 30 cm, 5 m, column \# N6825-10N, part number 08541 maintained at $25^{\circ} \mathrm{C}$ for the duration of the 30 minute analysis time. Detection was achieved at $214 \mathrm{~nm}$ and 
$280 \mathrm{~nm}$, with the $214 \mathrm{~nm}$ signal used for integration. A $100 \mu \mathrm{l}$ injection for a target column load of $10 \mu \mathrm{g}$ of anti-streptavidin was used for the $0.1 \mathrm{mg} / \mathrm{mL}$ concentration. For the higher concentrations of $1 \mathrm{mg} / \mathrm{mL}$ and $10 \mathrm{mg} / \mathrm{mL}$ anti-streptavidin, a target column load of $40 \mu \mathrm{g}$ of the antibody was injected at the start of each analysis. Simple integration of the peak areas was conducted in order to calculate percent area of the peaks. The areas for peaks eluting before the main peak were summed and referred to as high molecular weight (HMW) peaks. Likewise, peaks eluting after the main peak were also summed and labeled as low molecular weight (LMW) species. Plots of the percent main peak, percent high molecular weight and percent low molecular weight were made as a function of exposure time.

For size exclusion HPLC with multi-angle light scattering (MALS) detection, the method described above was coupled to a MALS system with the exception that the load of antistreptavidin was increased to $100 \mu \mathrm{g}$ for both the $1 \mathrm{mg} / \mathrm{mL}$ and $10 \mathrm{mg} / \mathrm{mL}$ samples to maximize signal intensity. Due to the limitation of detection for the MALS system, $0.1 \mathrm{mg} / \mathrm{mL}$ was not analyzed. Post UV detection, a Wyatt QELS Dawn EOS light scattering detector using a laser wavelength of $690.0 \mathrm{~nm}$ was added to the flow path and interfaced with an Optilab rEX refractive index detector in series. A refractive index of 1.3194 was used to adjust for the mobile phase. Immediately prior to the measurement of the samples, the system was calibrated using a known BSA (bovine serum albumin) solution.

\section{Gel Electrophoresis}

Samples of anti-streptavidin at $1 \mathrm{mg} / \mathrm{mL}$ were analyzed by SDS-PAGE with silver staining. Unexposed material was studied as well as material exposed to $302 \mathrm{~nm}$ for 15 and 60 minutes at $\mathrm{pH}$ 3.5, 5.0 and 8.0. Prior to analysis, aliquots of all samples were diluted with either 1.1 X non-reducing sample buffer or 1.1 X reducing sample buffer. The 1.1 X non-reducing 
sample buffer consisted of $68.89 \mathrm{mM}$ Tris $\mathrm{HCl} \mathrm{pH} \mathrm{7.0,} \mathrm{2.2 \%} \mathrm{SDS,} \mathrm{0.044 \%} \mathrm{bromophenol} \mathrm{blue,}$ and 22.22\% glycerol. The $1.1 \mathrm{X}$ reducing sample buffer consisted of $68.89 \mathrm{mM}$ Tris $\mathrm{HCl} \mathrm{pH}$ 7.0, 2.2\% SDS, $0.044 \%$ bromophenol blue, 22.22\% glycerol, and $111.11 \mathrm{mM}$ dithiothreitol. For both the non-reducing and reducing conditions, the samples were incubated at $60^{\circ} \mathrm{C}$ for 10 minutes in a water bath to denature and in the case of reducing conditions, to also reduce all disulfide linkages of the protein. After incubation, $10 \mu \mathrm{L}$ of each sample was placed into individual wells of a Novex 4-20\% tris-glycine 1.0 mm x 10 well gel (Invitrogen Life Sciences, part \# EC6025BOX). The gels were developed using Novex Tris-glycine SDS running buffer (Invitrogen Life Sciences, part \# LC2675) and a Powerease 500 ((Invitrogen Life Sciences, part \# EI8600) until the bromophenol blue marker reached the bottom of the gel. Once the sample had finished separating, both the non-reduced and reduced gels were subjected to silver staining as described below. Each gel was separately soaked in $50 \%(\mathrm{v} / \mathrm{v})$ ethanol for 5 to 7 minutes to dehydrate the gel. The gels were then immediately placed into 20\% (v/v) ethanol for at least 20 minutes but no longer than 2 hours at room temperature, after which the development process was began. First, the gels were independently placed into $0.02 \%$ sodium thiosulfate for 1 minute followed by twice rinsing with deionized water. The gels were then placed into a silver staining solution containing $2 \mathrm{~g}$ of silver nitrate and $750 \mu \mathrm{L}$ of formaldehyde in water for 20 to 60 minutes. The gels were then washed two times with deionized water and then placed for 2-3 minutes into a developer solution comprised of $60 \mathrm{~g}$ sodium carbonate, $500 \mu \mathrm{L}$ formaldehyde and $200 \mu \mathrm{L}$ of $2 \%$ (wt/vol.) sodium thiosulfate in $1 \mathrm{~L}$ of deionized water. Once the bands became visible, the developer solution was discarded and Destain I (Teknova, part number D0010) or 45\% methanol and 9\% acetic acid was added to stop over development of the gel. 
The gels were allowed to soak for a minimum of 10 minutes followed by a final rinse with deionized water. The gels were then photographed and dried.

\section{Differential Scanning Calorimetry}

A MicroCal Capillary Cell MicroCalorimeter, Model VP-DSC, was used to analyze 1mL aliquots of $1 \mathrm{mg} / \mathrm{mL}$ anti-streptavidin exposed for 15 and 30 minutes at $\mathrm{pH}$ 3.5, 5.0 and 8.0 as described above. Control samples of unexposed material at the same pH's were also evaluated. The reference cell contained only the sample buffer. The autosampler was maintained at $25^{\circ} \mathrm{C}$. The scan rate was $1^{\circ} \mathrm{C}$ per minute with a starting temperature of $15^{\circ} \mathrm{C}$ and an ending temperature of $95^{\circ} \mathrm{C}$. Upon completion of the first scan, a second scan was immediately conducted to examine the extent of reversibility for each sample. The resulting thermograms were analyzed using OriginPro software by fitting a baseline and obtaining the $\mathrm{T}_{\mathrm{m}} \mathrm{s}$.

\section{Intrinsic Tryptophan Fluorescence of Heat Induced Denaturation of Anti-streptavidin}

Fluorescence emission scan measurements were made using a PTI Fluorimeter, model 814. Three samples were prepared at a concentration of $0.1 \mathrm{mg} / \mathrm{mL}$, one sample was in $10 \mathrm{mM}$ sodium acetate $\mathrm{pH}$ 3.5, the second sample as in $10 \mathrm{mM}$ sodium acetate, $\mathrm{pH}$ 5.0, and the third sample was in $10 \mathrm{mM}$ sodium phosphate, $\mathrm{pH}$ 8.0. All samples were analyzed in triplicate $(\mathrm{n}=3)$. A Hellma quartz cuvette with a magnetic stirrer having a pathlength of $10 \mathrm{~mm}$ was used (part number 119.000F-QS). An excitation wavelength of 295nm was used with an excitation slit set to $0.50 \mathrm{~mm}$. The emission spectrum was scanned from 300 to $450 \mathrm{~nm}$ with an emission slit width of $0.5 \mathrm{~mm}$. The fluorimeter was fitted with a single cell peltier controlled cuvette holder (Quantum Northwest, TC 125). Measurements were made every $5^{\circ} \mathrm{C}$ from $10^{\circ} \mathrm{C}$ to $95^{\circ} \mathrm{C}$. Heating rate was $1^{\circ} \mathrm{C} /$ minute with an equilibration time of 3 minutes. The raw data were exported to Microsoft Excel and SigmaPlot for graphing using the average and standard 
deviation of the three individual analyses. The fluorescence intensity of the corresponding buffer was subtracted from the sample intensity for each sample individually.

To generate the fluorescence peak maximum versus temperature graphs, the data was exported into Origin, version 8.0 allowing the first derivative to be generated for each sample. The data was then plotted and fit to a quadratic equation using Microsoft Excel allowing the calculation of the peak maximum. The peak maximum was then simply plotted as a function of temperature. To obtain melting temperature $\left(T_{m}\right)$ values, the maximum and minimum peak positions were subtracted from each other, the value divided by two and added back to the minimum value. Using the graph of fluorescence peak maximum $\left(\mathrm{F}_{\max }\right)$ versus temperature, the $\mathrm{T}_{\mathrm{m}}$ could then be determined.

\section{Intrinsic Tryptophan Fluorescence}

Samples of anti-streptavidin at both $1.0 \mathrm{mg} / \mathrm{ml}$ and $10.0 \mathrm{mg} / \mathrm{mL}$ were exposed to $302 \mathrm{~nm}$ UV light at $4^{\circ} \mathrm{C}$ for $0,1,5,15,30,45$, and 60 minutes. Three separate buffer solutions were examined: $10 \mathrm{mM}$ sodium acetate, $\mathrm{pH}$ 3.5, $10 \mathrm{mM}$ sodium acetate, $\mathrm{pH}$ 5.0, and $10 \mathrm{mM}$ sodium acetate, $\mathrm{pH}$ 8.0. The intrinsic fluorescence of the samples was monitored at $25^{\circ} \mathrm{C}$ using a PTI Fluorimeter, model 814 . The sample was excited at $295 \mathrm{~nm}$ with both the excitation and emission slits set to $0.5 \mathrm{~mm}$. For the low concentration of $1.0 \mathrm{mg} / \mathrm{mL}$ anti-streptavidin, a Hellma (part number 105.251 QS) quartz cuvette with a pathlength of $3 \mathrm{~mm}$ was used. For the higher concentration of $10 \mathrm{mg} / \mathrm{mL}$ anti-streptavidin, a Hellma (part number 105.252-QS) quartz cuvette with a pathlength of $1.5 \mathrm{~mm}$ was used. The data were exported and plotted in SigmaPlot.

\section{Near UV Circular Dichroism}

Near UV circular dichroism measurements were made for the $10 \mathrm{mg} / \mathrm{mL}, 1.0 \mathrm{mg} / \mathrm{mL}$ and $0.1 \mathrm{mg} / \mathrm{mL}$ anti-streptavidin solutions described above using quartz Hellma cells with path 
length of $0.01,0.10$ and $1.00 \mathrm{~cm}$ (part numbers 106-0.01-40, 106-0.10-40, and 110-QS). All CD measurements were made averaging 3 scans using a Jasco J-810-150S spectropolarimeter at $25^{\circ} \mathrm{C}$ set with a response time of 16 seconds, data pitch of $1 \mathrm{~nm}$, and a scanning speed of 20nm/min. Each sample was scanned from 350 to $250 \mathrm{~nm}$. The $1 \mathrm{mg} / \mathrm{mL}$ and $10 \mathrm{mg} / \mathrm{mL}$ samples were analyzed in triplicate. For all samples, the data were exported into an Excel spreadsheet where the buffer scan was subtracted from the individual sample signals $(n=3)$. The mean residue ellipticies (MRE, deg $\mathrm{cm}^{2} / \mathrm{dmole}$ ) were calculated using equation (3), where $\mathrm{M}_{0}$ is the mean residue weight (107.57 Da/residue), $\Theta$ is the observed ellipticity (mdeg), $l$ is the light path, and $\mathrm{c}$ is the concentration $(\mathrm{mg} / \mathrm{mL}){ }^{36}$ The average of the MRE $(\mathrm{n}=3)$ was calculated using Excel. The data were then exported and the average MRE was graphed using SigmaPlot.

$$
\operatorname{MRE}=\frac{M_{0} \times \theta}{10 \times l \times c}
$$

\section{2nd Derivative Ultraviolet-visible Spectroscopy}

Samples of anti-streptavidin at both $1.0 \mathrm{mg} / \mathrm{ml}$ and $10.0 \mathrm{mg} / \mathrm{mL}$ were exposed to $302 \mathrm{~nm}$ UV light at $4^{\circ} \mathrm{C}$ for $0,1,5,15,30,45$, and 60 minutes at $\mathrm{pH}$ values of $3.5,5.0$ and 8.0 . UV-vis absorbance measurements were made using aliquots of the sample in a Hellma quartz cell with a $1 \mathrm{~mm}$ path length (110-QS, $1 \mathrm{~mm}$ ) and an Agilent $8453 \mathrm{UV}$-vis spectrometer blanked against the sample buffer dependent upon the $\mathrm{pH}$ of the sample. Anti-Streptavidin was determined to have molar extinction coefficient of $1.586 \mathrm{~mL} \times \mathrm{mg}^{-1} \times \mathrm{cm}^{-1}$ (Amgen internal data). The spectrometer integration was set to 25 seconds with an interval of $1 \mathrm{~nm}$. Data analysis was begun using Agilent's UV-Vis ChemStation software by taking the second derivative of the absorbance A $\left(d^{2} \mathrm{~A} / \mathrm{d} \lambda^{2}\right)$ using a nine point data filter with a third-order Savitzky-Golay polynomial fit. A 
spline function using 50 interpolated points between each raw data point was then applied to the resulting spectra such that the resolution was $0.02 \mathrm{~nm} .{ }^{48}$ The data were then exported to OriginPro for peak assignment and plotting.

\section{Far UV Circular Dichroism}

Far UV circular dichroism using quartz Hellma cells (part number 110-QS, 1mm and 106-0.10-40) having a path length of 1.0 and $0.10 \mathrm{~mm}$ were made for both the $1.0 \mathrm{mg} / \mathrm{mL}$ and 10 $\mathrm{mg} / \mathrm{mL}$ anti-streptavidin solutions described above. All CD measurements were made averaging 3 scans using a Jasco J-810-150S spectropolarimeter at $25^{\circ} \mathrm{C}$ set with a response time of 16 seconds, data pitch of $1 \mathrm{~nm}$, and a scanning speed of $20 \mathrm{~nm} / \mathrm{min}$. Each sample was scanned from 250 to $190 \mathrm{~nm}$. All samples were analyzed in triplicate. Excel was used to subtract the signal of the sample buffer from the signal for the individual samples as well as to calculate the MRE and its average value $(n=3)$. SigmaPlot was used to plot the average MRE data.

\section{FTIR spectroscopy}

Infrared spectra were collected for the $10 \mathrm{mg} / \mathrm{mL}$ anti-streptavidin samples using an $\mathrm{ABB}$ Bomem (Que., Canada) MB Series FTIR spectrometer. The data were collected using a Biocell obtained from Bio Tools, Inc (part number BCT1006, serial number SPS2009_08) having a fixed pathlength of $6.2 \mu \mathrm{m}$. Each spectrum was obtained by collecting 128-scan interferograms in a single-beam mode having $4 \mathrm{~cm}^{-1}$ resolution. Reference scans containing only the buffer were made for each of the $\mathrm{pH}$ conditions to be used later for subtraction from the corresponding $\mathrm{pH}$ samples to yield that of just the protein under each condition. For confirmation purposes, FTIR spectra for each of the conditions studied at $10 \mathrm{mg} / \mathrm{mL}$ and $1 \mathrm{mg} / \mathrm{mL}$ were also recorded at room temperature using a Bruker Vertex 70 Fourier transform infrared spectrometer, equipped with an MCT detector. The samples were measured directly in the AquaSpec Cell that employs $\mathrm{CaF}_{2}$ 
windows separated by a $6 \mu \mathrm{m}$ spacer. For each spectrum, a 256-scan interferogram was collected in a single beam mode, with a $4 \mathrm{~cm}^{-1}$ resolution. Reference spectra were recorded under identical conditions with the corresponding buffer in the cell. The reference spectra for the buffer blank were subtracted from the protein spectra. Regardless of the instrument used, once the protein spectra were obtained they were subjected to second derivative analysis using a Savitsky-Golay derivative function followed by baseline correction and normalization and finally plotted using SigmaPlot software. Data obtained using the Bruker instrument is reported here. ${ }^{49-}$ 52

\section{Ellman's Test for free sulfhydryls}

Immediately prior to analysis, a $4 \mathrm{mM}$ DTNB solution in $50 \mathrm{mM}$ Tris $\mathrm{HCl}, \mathrm{pH} 8.0$ and 8 M Guanidine $\mathrm{HCl}$ was prepared. At the same time a stock solution of N-acetyl-L-cysteine (NAC) was also prepared to a final concentration of $2 \mathrm{mM} \mathrm{NAC}$ and $25 \mathrm{mM}$ Tris $\mathrm{HCl}, \mathrm{pH} 8.0$ in deionized water and used within 30 minutes. From the stock NAC solution, NAC standards were prepared to a final concentration of $0,4,8,12,16,20$, 28, and $40 \mathrm{nMols}$ in Tris $\mathrm{HCl} \mathrm{pH} 8$ and $8 \mathrm{M}$ guanidine $\mathrm{HCl}$. The standards were incubated with $216 \mu \mathrm{l}$ Ellman's reagent (approximately 3.37 mM 5,5'-dithio-bis(2-nitrobenzoic acid (DTNB)) in the dark for 15 minutes. Again, at the same time, samples protected from light of $10 \mathrm{mg} / \mathrm{mL}$ of anti streptavidin in $10 \mathrm{mM}$ sodium acetate at $\mathrm{pH} 3.5$ and 5.0 as well as $10 \mathrm{mM}$ sodium phosphate, $\mathrm{pH} 8.0$ were compared to samples exposed to $302 \mathrm{~nm}$ light for 30 minutes. All samples were prepared in triplicate by taking $40 \mu \mathrm{l} 1 \mathrm{M}$ Tris HCl, pH 8.0, $0.696 \mu \mathrm{l} 8 \mathrm{M} \mathrm{GuHCl}$, and $200 \mu \mathrm{L}$ of the sample and incubating it with $11.4 \mu \mathrm{l}$ Ellman's reagent (4 mM DTNB) in the dark for 15 minutes. The absorbance of all solutions at 412nm was immediately measured using an Agilent 8453 UV-vis spectrometer blanked against the sample buffer with DTNB. Using the standard curve plotted 
using Microsoft Excel, the obtained equation from a linear fit of the data, the absorbance of each sample, and the number of cysteines in the primary structure of anti streptavidin at 32, the \% free sulfhydryls was obtained.

\section{Results:}

All samples were visually inspected prior to analysis. Under the conditions studied, no precipitation of anti-streptavidin was observed. Using ferrioxalate actinometry, it was determined that the samples were exposed to an incidence photon flux of $16.32 \times 10^{20}$ photons/s (1074.20 J/s). Based on the Modified Lowry Protein Assay, no substantial loss of protein was observed upon exposure to ultraviolet light.

\section{Effect of light on aggregation}

Following exposure to 302nm light for $0,1,5,15,30$, 45, and 60 minutes, the samples were analyzed by size exclusion (SEC) HPLC. The chromatograms showed several important differences where the most dramatic difference was caused by $\mathrm{pH}$ of the sample. At $\mathrm{pH} 3.5$, the loss of the main peak was accompanied by an increase in an earlier eluting peak at approximately 13.5 minutes (Figure 1). The main peak also broadened upon light exposure. At pH 5.0, the main peak also broadened upon light exposure, but to a smaller extent; in addition, we observed a concomitant formation not only of the earlier eluting peak at 13.5 minutes, but also an additional peak eluting at 12.5 minutes. For the $\mathrm{pH} 8.0$ samples, a growth of the peaks at 13.5 and 12.5 minutes was observed as well as earlier eluting peaks at approximately 11.5 and 10.0 minutes. These trends hold for all three concentrations of anti-streptavidin solutions studied. 

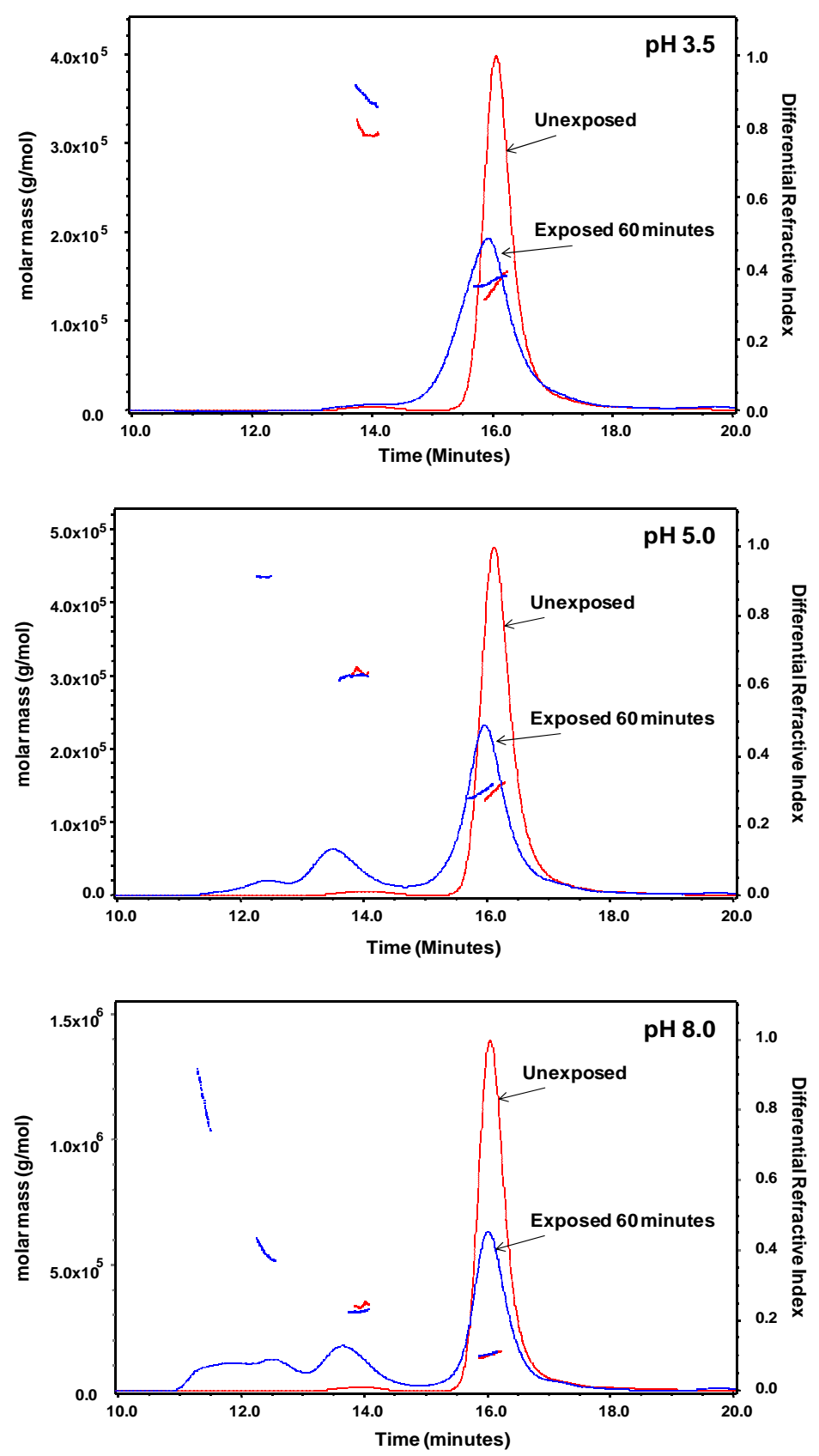

Figure 1. Size Exclusion HPLC MALS for $1 \mathrm{mg} / \mathrm{mL}$ anti-streptavidin. The right vertical axis labeled as Differential Refractive Index shows the change in refractive index as a function of the retention time producing a typical chromatogram as the sample elutes. The left vertical axis labeled as Molar Mass ( $\mathrm{g} / \mathrm{mol})$ is associated with the short lines under the main peak of the chromatogram and the short lines above the high molecular weight species indicating the molar mass of the species at the same retention time. 
For all conditions examined, growth in earlier eluting peaks along with broadening of the main peak could be observed in as short as 1 minute of exposure to 302nm light. These differences were not accounted for by storage of anti-streptavidin at the solution conditions examined as anti-streptavidin was found to be stable in non-irradiated control solutions during the analysis time (data not shown). To examine if a pH-shift alone following photolysis could account for the increased aggregation as compared to that observed at $\mathrm{pH} 3.5$, an experiment was conducted in which a $1 \mathrm{mg} / \mathrm{mL}$ sample in $10 \mathrm{mM}$ sodium acetate, $\mathrm{pH} 3.5$ was exposed to $302 \mathrm{~nm}$ light and then diluted into $10 \mathrm{mM}$ sodium phosphate, $\mathrm{pH}$ 8. The results in Figure 1 show that samples exposed to light at $\mathrm{pH} 8.0$ should have a greater extent of high molecular weight (HMW) aggregates than those at $\mathrm{pH}$ 3.5. Yet, it was observed that the sample irradiated at $\mathrm{pH}$ 3.5 followed by shifting the $\mathrm{pH}$ to 8.0 showed a similar amount of HMW aggregates as that observed for the pH 3.5 sample that was exposed to the light and not diluted (data not shown). This observation indicated that the formation of aggregates during photolysis is dependent upon the $\mathrm{pH}$ of the solution. Adjusting the $\mathrm{pH}$ after photolysis did not result in an increase in aggregates.

From the sequence of anti-streptavidin, the molecular weight of the mAb monomer was determined to be $142,159.5 \mathrm{Da}$. Analysis by SEC MALS of the $1 \mathrm{mg} / \mathrm{mL}$ samples exposed to $302 \mathrm{~nm}$ light for 60 minutes demonstrated that a species having approximately the same mass as a dimer was the predominate species formed at all three $\mathrm{pH}$ 's. At $\mathrm{pH}$ 5.0, in addition to dimer formation, a trimer was also observed, while at $\mathrm{pH} 8.0$ additional HMW species including tetramer and other larger species were seen. The $10 \mathrm{mg} / \mathrm{mL}$ data was similar to the $1 \mathrm{mg} / \mathrm{mL}$ data and therefore for ease of explanation is not shown. 
To further illustrate the differences in rates of aggregation with $\mathrm{pH}$ and protein concentration the percent HMW species was plotted against the duration of light exposure (see Figure 2). At pH 3.5 no change was observed in the concentration of HMW species over a 60 minute exposure time while a slight increase was observed at the same $\mathrm{pH}$ with increasing protein in the order of $0.1 \mathrm{mg} / \mathrm{mL}<1 \mathrm{mg} / \mathrm{mL}<10 \mathrm{mg} / \mathrm{mL}$. In contrast, aggregation increased at all protein concentrations during exposure at $\mathrm{pH} 5$ and $\mathrm{pH} 8$ with the increase at $\mathrm{pH} 8$ greater than that at $\mathrm{pH}$ 5. Across the protein concentrations distinct differences were seen in the aggregation rates with the $10 \mathrm{mg} / \mathrm{mL}$ samples showing a linear increase and the 0.1 and $1 \mathrm{mg} / \mathrm{mL}$ showing a faster phase for the initial time points followed by a shallower linear increase over the remaining time period. While an increase in the low molecular weight species can also be discerned by SEC analysis, the data is not reported here because of the complexity in the interpretation due to disulfide bond formation and non-covalent interactions between the heavy and light chains. 

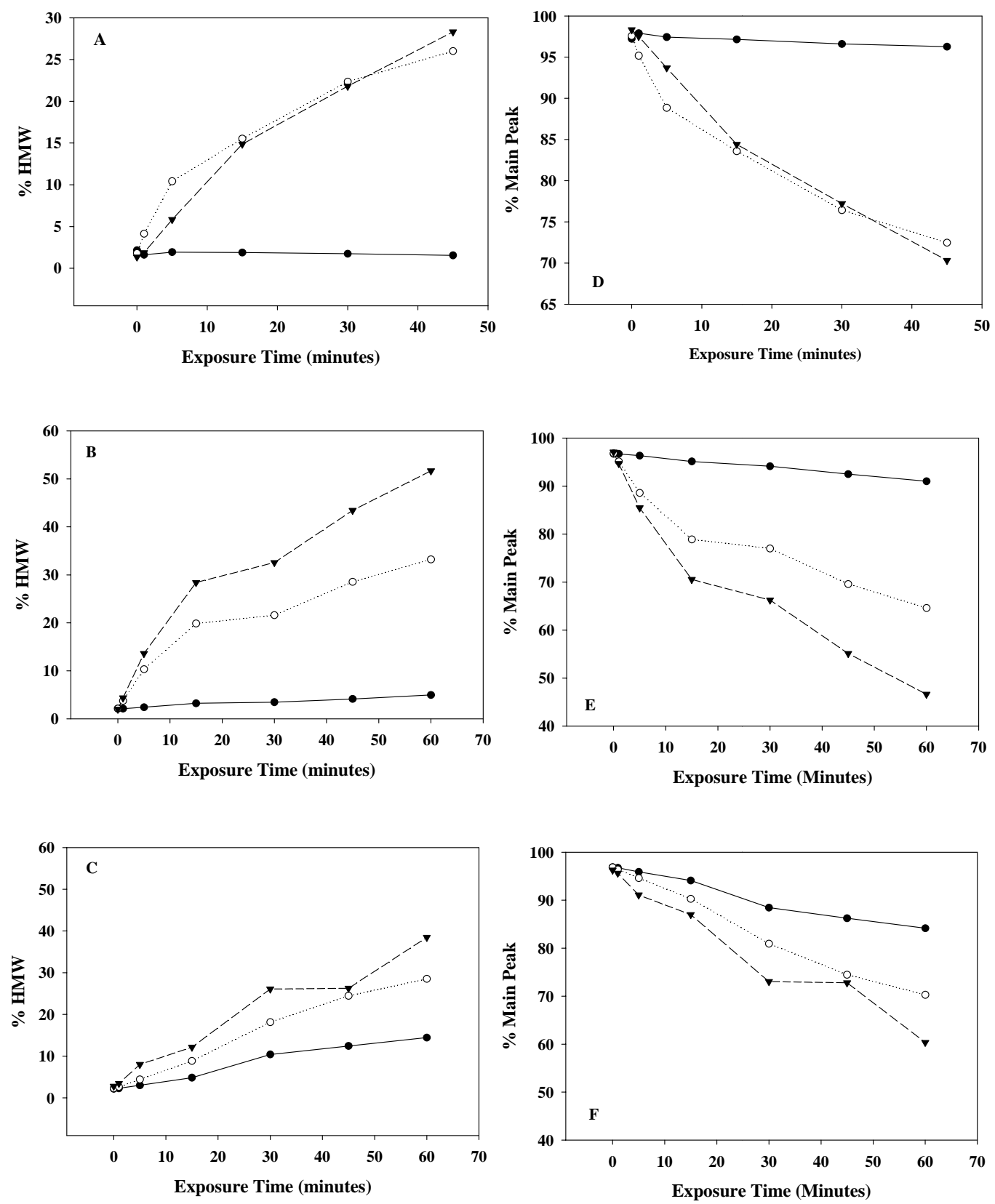

Figure 2. Rate of growth of HMW, loss of main peak for $0.1,1$, and $10 \mathrm{mg} / \mathrm{mL}$ antistreptavidin as a function of exposure time. Graphs $\mathrm{A}$ to $\mathrm{C}$ show the rate of formation of the percent high molecular weight species over increasing exposure time for 0.1 (Graph A), 1.0 (Graph B), and 10 $\mathrm{mg} / \mathrm{mL}$ (Graph C) respectively. Graphs D-F show the rate of decrease in the percent main peak area over increasing exposure time for 0.1 (Graph D), 1.0 (Graph E), and $10 \mathrm{mg} / \mathrm{mL}$ (Graph F) respectively. $(\bullet \mathrm{pH} \mathrm{3.5,} \mathrm{\bullet} \mathrm{pH} 5, \nabla \mathrm{pH} 8)$. 
Evaluation of the non-reduced SDS-PAGE reveals the expected growth in aggregation (Figure 3) that is observed by SE HPLC. For reference purposes, a molecular weight ladder was loaded in the first well of each gel ( lane 1). Unexposed samples were loaded into lanes 2, 5, and 8 for $\mathrm{pH}$ 3.5, 5.0, and 8.0 respectively. Samples exposed to $302 \mathrm{~nm}$ for 15 minutes were loaded into lanes 3, 6, and 9 for $\mathrm{pH}$ 3.5, 5.0, and 8.0 respectively. Similarly, samples exposed to 302nm for 30 minutes were loaded into lanes 4, 7, and 10 for $\mathrm{pH}$ 3.5, 5.0, and 8.0 respectively. From the amino acid sequence, the heavy chain has a molecular weight of approximately $48 \mathrm{kDa}$ without glycosylation while the light chain has a molecular weight of approximately $23 \mathrm{kDa}$ and does not have a glycosylation site. The band slightly below the intact anti-streptavidin band is likely a form of the antibody that is missing a single light chain and can be observed in the nonreduced gel for all samples. A fairly dark band in the non-reduced gel associated with the light chain is also readily noticeable. Both the mAb missing a light chain as well as the light chain only are likely carryover from the purification process as they are in all of the unexposed samples. Most apparent is the appearance of multiple bands above the heavy chain band having high molecular weights. These bands appear to be more intense upon longer exposure time. This holds for all three pH's and is in good agreement with that observed in the size exclusion HPLC data. The number of bands and the intensity also appear to increase with increasing $\mathrm{pH}$. There was also observed an increase in lower molecular weight material between 36.5 and 55.4 kDa upon exposure to $302 \mathrm{~nm}$ light. The presence of these low molecular weight species demonstrates that increasing light exposure causes antibody fragmentation. 


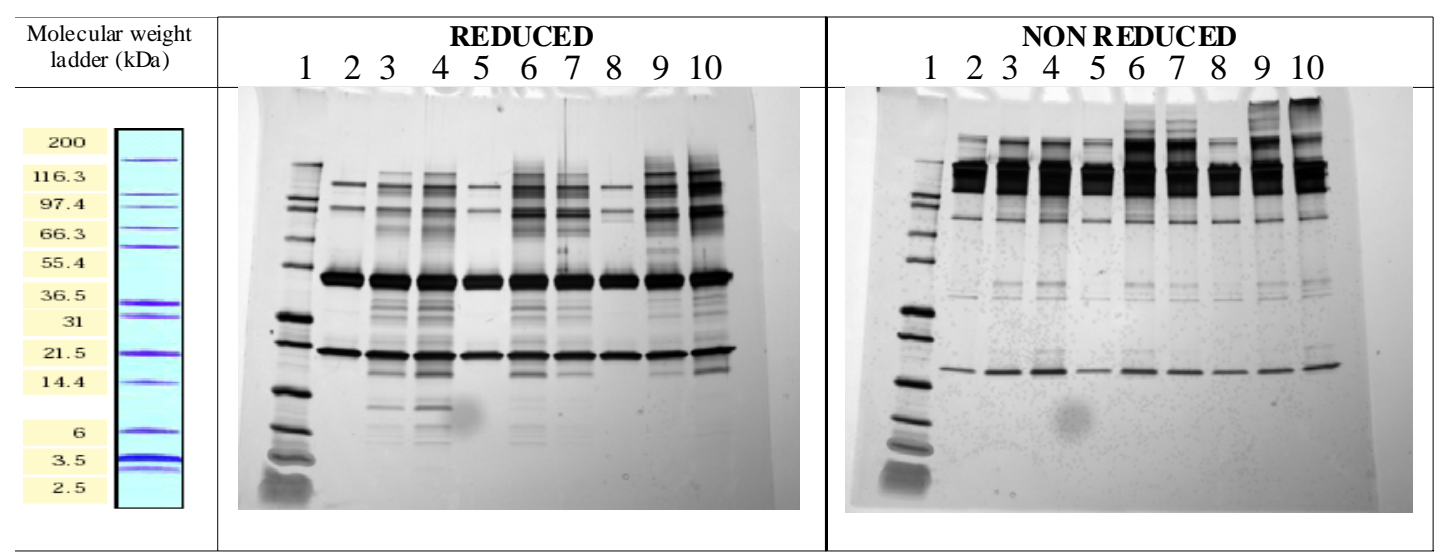

Figure 3. SDS-PAGE silver stained of $1 \mathrm{mg} / \mathrm{mL}$ anti-streptavidin exposed up to 30 minutes to light at 302nm in three different buffer systems, both reduced and non-reduced gels. Lane 1 molecular weight ladder (kDa), Lane 2 pH 3.5 unexposed, Lane 3 pH 3.5 exposed 15 minutes, Lane 4 pH 3.5 exposed 30 minutes, Lane 5 pH 5.0 unexposed, Lane 6 pH 5.0 exposed 15 minutes, Lane 7 pH 5.0 exposed 30 minutes, Lane 8 pH 8.0 unexposed, Lane 9 pH 8.0 exposed 15 minutes, Lane $10 \mathrm{pH} 8.0$ exposed 30 minutes. 
The reduced SDS-PAGE gel on the left-hand side of Figure 3 clearly shows the heavy and light chains for anti-streptavidin. Most noticeable in comparison to the non-reduced gels, high molecular weight bands remain demonstrating the presence of non-reducible aggregates in all exposed samples. The increase in the high molecular weight species, trends with increasing $\mathrm{pH}$ and exposure time. The longer the exposure time, the more intense the high molecular weight bands become. Again, similar to the size exclusion data, there is an increase in the number of aggregate bands with increasing $\mathrm{pH}$. A comparison with the molecular weight markers, provides a crude estimation of the bands molecular weights and suggests the growth of dimer, trimer, and higher order oligomer species with increasing exposure times. There is also a corresponding growth in low molecular weight clip species. This indicates that along with nonreducible aggregates, there are also a variety of reducible species having molecular weights of less than that of the intact antibody, intact heavy chain as well as the intact light chain. These species can be observed below the molecular weight of the intact antibody, intact heavy chain and intact light chain. The new bands can be observed most readily for the $\mathrm{pH} 3.5$ exposed samples. Specifically for $\mathrm{pH} 3.5$ exposed samples, there can be seen several new clip species smaller than the light chain. There are also a series of new bands between 23 to $48 \mathrm{kDa}$ that become darker with increasing exposure time and decreasing $\mathrm{pH}$. For $\mathrm{pH} 5.0$ and 8.0, the clipping is most apparent by the appearance of bands between the heavy and light chains, although there also appears to be growth in a species having a molecular weight less than that of the light chain for all three pH's.

\section{Effect of light on conformation}

The conformation of the anti-streptavidin mAb was assessed using multiple biophysicial techniques in combination with thermal stress following photoirradiation. The thermal stability 
by DSC was examined by collecting thermograms of $1 \mathrm{mg} / \mathrm{mL}$ anti streptavidin unexposed and then exposed for 15 and 30 minutes for each of the three pHs (see Fig. 4). Under the conditions studied, the thermal unfolding of anti-streptavidin was irreversible likely as a result of aggregate formation. As a result equilibrium thermodynamics could not be used to obtain accurate thermodynamic parameters. ${ }^{25}$ Despite this limitation, DSC and fluorescence measurements allowed for a number of observations to be made. Three to four distinct unfolding transitions are observed for all thermograms, and in general are considered to be apparent melting transitions. These transitions have not been specifically assigned for this antibody so their exact identity remains unknown at this point. For reference purposes, typically the first melting transition is assigned as either the $\mathrm{CH} 2$ domain or the Fab, with the third peak being assigned as the $\mathrm{CH} 3$ domain. ${ }^{25,53}$ Whether or not this holds for this antibody, it can still be observed from an overlay of the three unexposed samples that there is clearly a shift towards higher temperatures with increasing $\mathrm{pH}$, going from approximately $65^{\circ} \mathrm{C}$ for $\mathrm{pH} 3.5$ to $72^{\circ} \mathrm{C}$ for $\mathrm{pH} 8$ for the first unfolding transition. Under all three buffer conditions, upon exposure to UV light, the unfolding transitions appear to become broader, indicating the presence of unfolding intermediates, although there does not appear to be any significant shift in the $T_{m}$ values. The trend becomes more pronounced with increasing exposure times such that a 30 minute exposure shows a dramatic broadening of the three transition peaks. The trend for broadening of the apparent melting transitions also becomes more apparent at higher $\mathrm{pH}$ 's.

Investigation of the tertiary structure by intrinsic fluorescence was performed for all three buffer systems at $0.1 \mathrm{mg} / \mathrm{mL}, 1 \mathrm{mg} / \mathrm{mL}$ or $10 \mathrm{mg} / \mathrm{mL}$ (not shown) anti streptavidin (see Figures 5 and 6). The intrinsic fluorescence during heating following photolysis was further used to examine the conformational integrity of the mAb. 

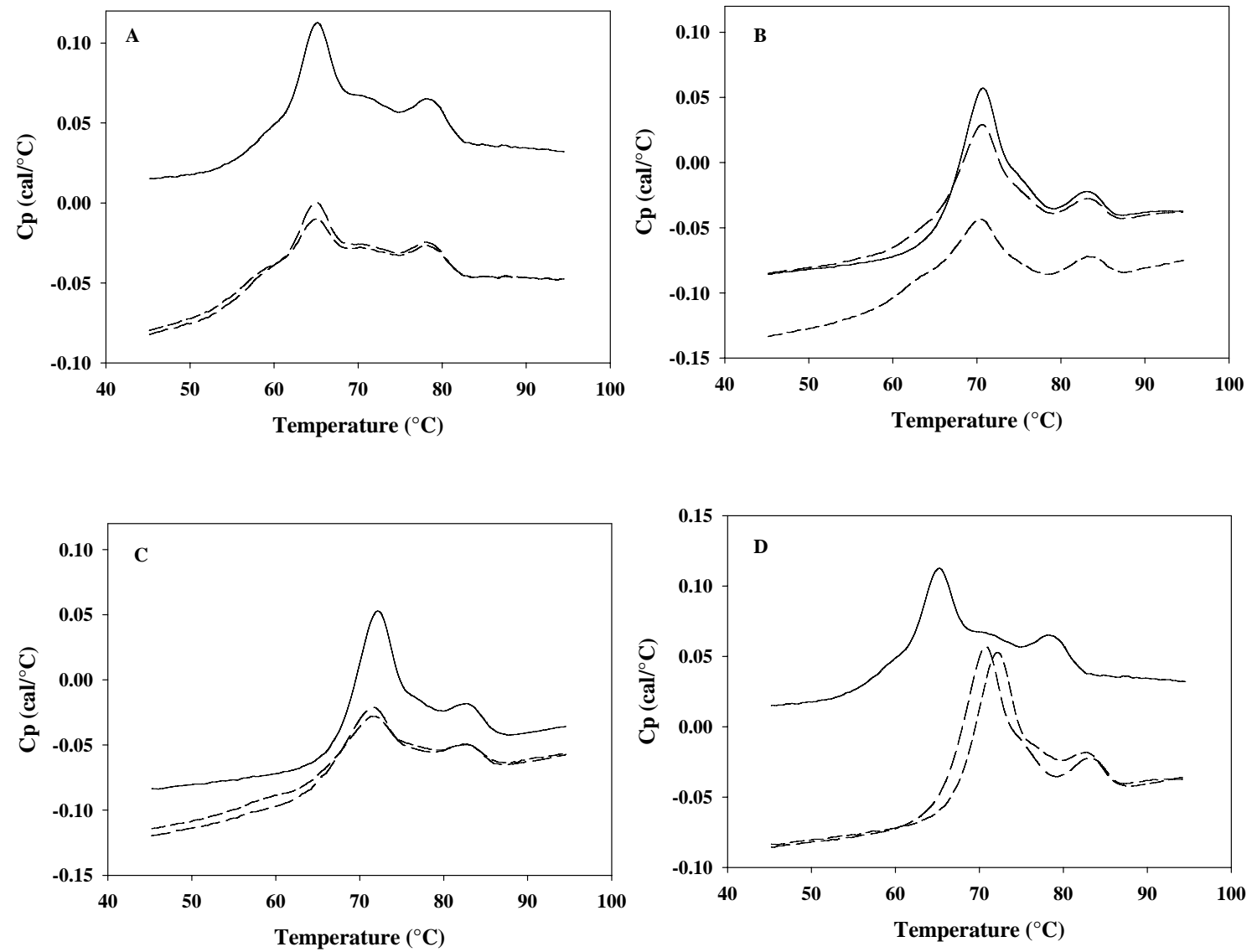

Figure 4. Differential scanning calorimetry thermograms of $1 \mathrm{mg} / \mathrm{mL}$ of anti streptavidin in 10 mM sodium acetate pH 3.5 (Graph A), 10mM sodium acetate (Graph B), 10 mM sodium phosphate pH 8.0 (Graph C) exposed to 302nm light from 0, 15, and 30 minutes. Comparison of differential scanning calorimetry thermograms of $1 \mathrm{mg} / \mathrm{mL}$ of anti streptavidin in $10 \mathrm{mM}$ sodium acetate $\mathrm{pH} 3.5$ and 5.0 and $10 \mathrm{mM}$ sodium phosphate $\mathrm{pH} 8.0$ is shown in the lower right panel (Graph D). All thermograms were baseline corrected using the corresponding buffer thermogram. ( - pH 3.5,-- $\mathrm{pH}$ 5.0,-- - pH 8.0) 

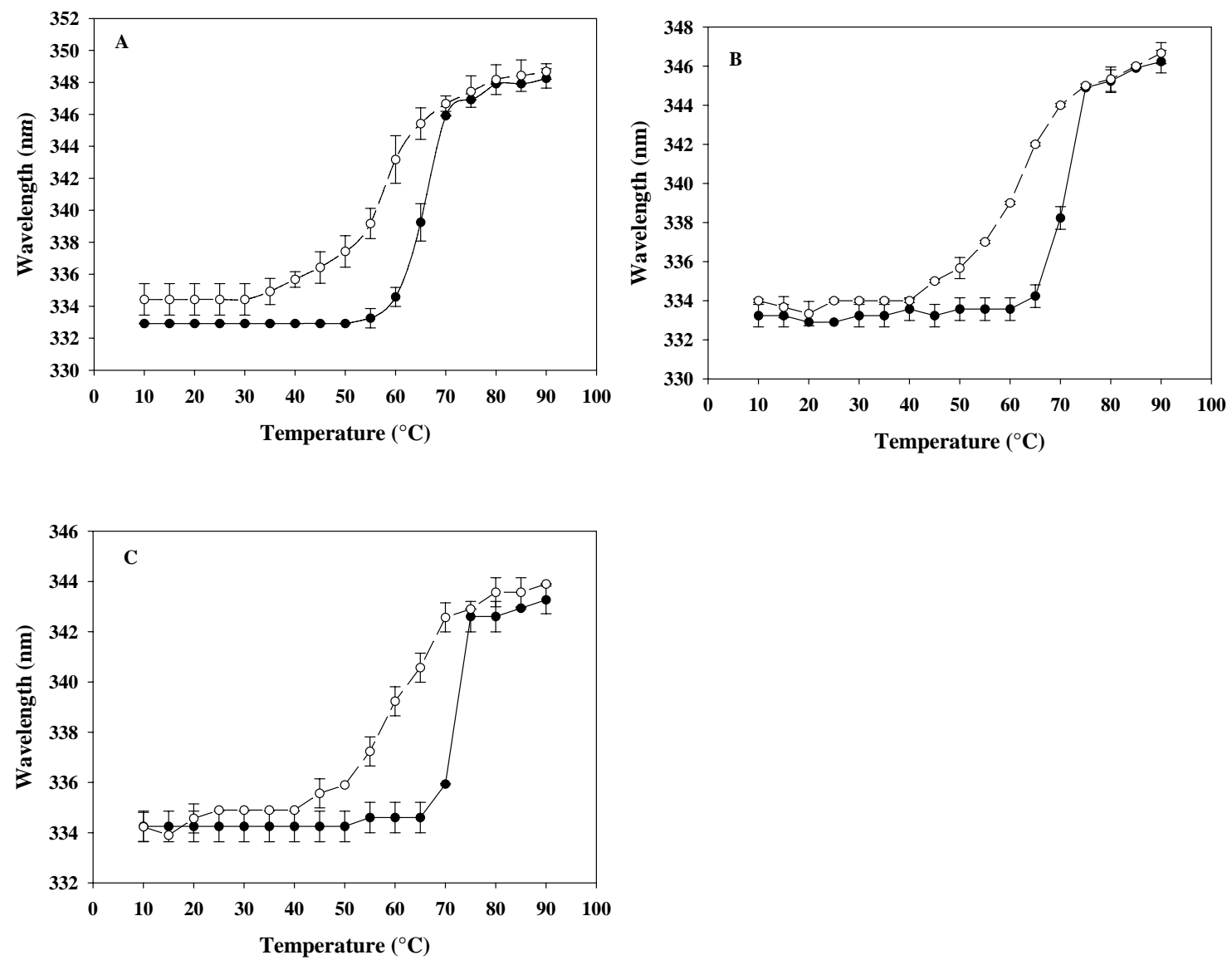

Figure 5. Fluorescence maximum as a function of temperature ranging from $10^{\circ} \mathrm{C}$ to $90^{\circ} \mathrm{C}$ for $0.1 \mathrm{mg} / \mathrm{mL}$ anti-streptavidin unexposed and exposed for 60 minutes to $302 \mathrm{~nm}$ light. Excitation was at $295 \mathrm{~nm}$ with emission scanned from 300 to $450 \mathrm{~nm}$. For each condition, measurements were made in triplicate $(n=3)$ with the average of these measurements plotted here using standard deviation to generate the error bars. Graphs $\mathrm{A}, \mathrm{B}$, and $\mathrm{C}$ represent $\mathrm{pH}$ 3.5, $\mathrm{pH}$ 5.0, and $\mathrm{pH} 8.0$ respectively. ( $\bullet$ unexposed, $\bullet$ exposed). 
Plots of the $F_{\max }$ versus temperature showed that there was little to no shifts in the fluorescence peak position for the unexposed material up to $60^{\circ} \mathrm{C}$ with a red shift in the $\mathrm{F}_{\max }$ during the unfolding transition. The final $\mathrm{F}_{\max }$ attained for each $\mathrm{pH}$ showed a decrease with increasing pH from $348 \mathrm{~nm}$ at pH 3.5 to $346 \mathrm{~nm}$ at pH 5 and $343 \mathrm{~nm}$ at $\mathrm{pH} 8$. The midpoints of the transitions were $66{ }^{\circ} \mathrm{C}$ for $\mathrm{pH} 3.5$ and $70.5{ }^{\circ} \mathrm{C}$ for $\mathrm{pH} 5$ and 72.0 for $\mathrm{pH} 8$ in agreement with the DSC data obtained for each of the samples. In all cases, upon exposure to $302 \mathrm{~nm}$ light for 60 minutes, there is a significant broadening of the transition as observed by an earlier red shift in the peak position, typically by as much as $20^{\circ} \mathrm{C}$ before that observed for the unexposed material. Again, the pH 3.5 sample exposed for 60 minutes showed the lowest midpoint of the transition value of approximately $58^{\circ} \mathrm{C}$, while $\mathrm{pH} 5.0$ had a value of $62^{\circ} \mathrm{C}$. The $\mathrm{pH} 8.0$ sample exposed for 60 minutes had a value of approximately $60^{\circ} \mathrm{C}$. The onset of the thermal transitions was also affected by $\mathrm{pH}$ with the $\mathrm{pH} 3.5$ sample deviating from baseline at approximately $35^{\circ} \mathrm{C}$ and showing a multiphasic transition through the thermal unfolding process. Material exposed at pH 5.0 also demonstrated a multiphasic transition with a deviation from baseline initiating at approximately $45^{\circ} \mathrm{C}$. Like the $\mathrm{pH} 5.0$ exposed samples, the mAb exposed at $\mathrm{pH} 8.0$ showed a deviation from baseline beginning at $45^{\circ} \mathrm{C}$ and demonstrating an unfolding curve with a shape similar to a cooperative transition. The final $\mathrm{F}_{\max }$ increased from the control sample by almost 1 $\mathrm{nm}$ with a final value of $344.0 \mathrm{~nm}$. The fluorescence intensity of $1 \mathrm{mg} / \mathrm{mL}$ anti streptavidin at $25^{\circ} \mathrm{C}$ following increasing light exposure times at $\mathrm{pH} 3.5$ and $\mathrm{pH}$ 5.0, and $\mathrm{pH} 8.0$ was monitored using an excitation of $295 \mathrm{~nm}$. Figure 6 . A decrease in peak intensity up to $38 \%$ of the original intensity was observed with increasing exposure time for all three $\mathrm{pH}$ 's. 

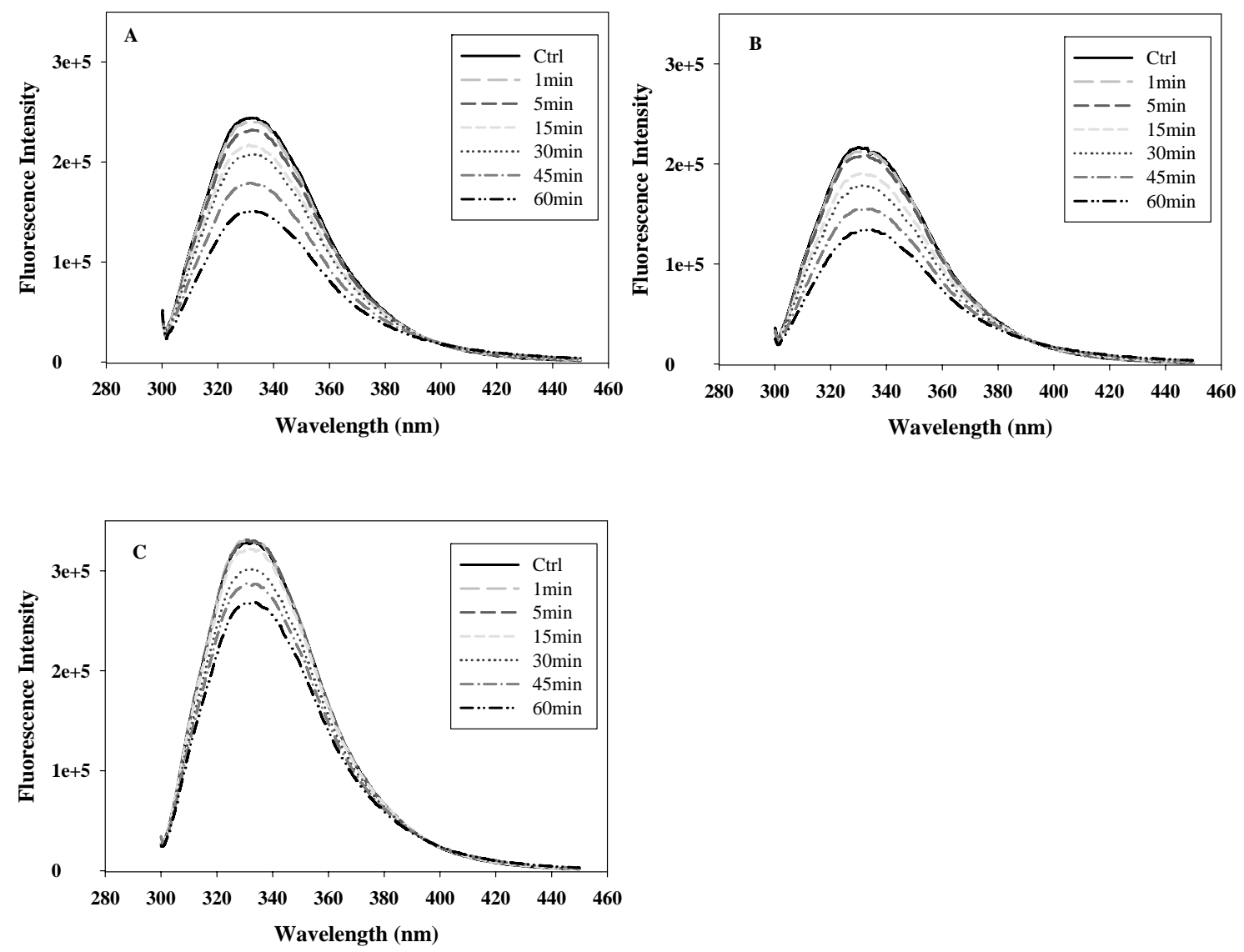

Figure 6. Intrinsic fluorescence at $25^{\circ} \mathrm{C}$ of buffer subtracted $1 \mathrm{mg} / \mathrm{mL}$ anti streptavidin in 10 mM sodium acetate pH 3.5 (Graph A), 10mM sodium acetate pH 5.0 (Graph B), and 10 mM sodium phosphate pH 8.0 (Graph C) with increasing exposure times of 0, 1, 5, 15, 30, 45, 60 minutes. 
An examination of the tertiary structure by Near UV CD revealed changes in the spectra obtained for the $1 \mathrm{mg} / \mathrm{mL} \mathrm{pH} 3.5$ solution exposed for 60 minutes to $302 \mathrm{~nm}$ light as compared to that of unexposed material, but failed to show significant differences at $10 \mathrm{mg} / \mathrm{mL}$ (see Figure 7). At $\mathrm{pH} 5$, the averaged spectra of the UV-exposed $\mathrm{mAb}$ are identical to that of the unexposed $\mathrm{mAb}$ for both the 1 and $10 \mathrm{mg} / \mathrm{mL}$ solutions. At $\mathrm{pH}$, the spectra obtained after UV-exposure of $1 \mathrm{mg} / \mathrm{mL} \mathrm{mAb}$ show a decrease in the peak at approximately $295 \mathrm{~nm}$ associated with tryptophan residues when compared to the spectra of unexposed mAb. This however was not seen in the 10 $\mathrm{mg} / \mathrm{mL} \mathrm{mAb}$ solution at the same $\mathrm{pH}$. 

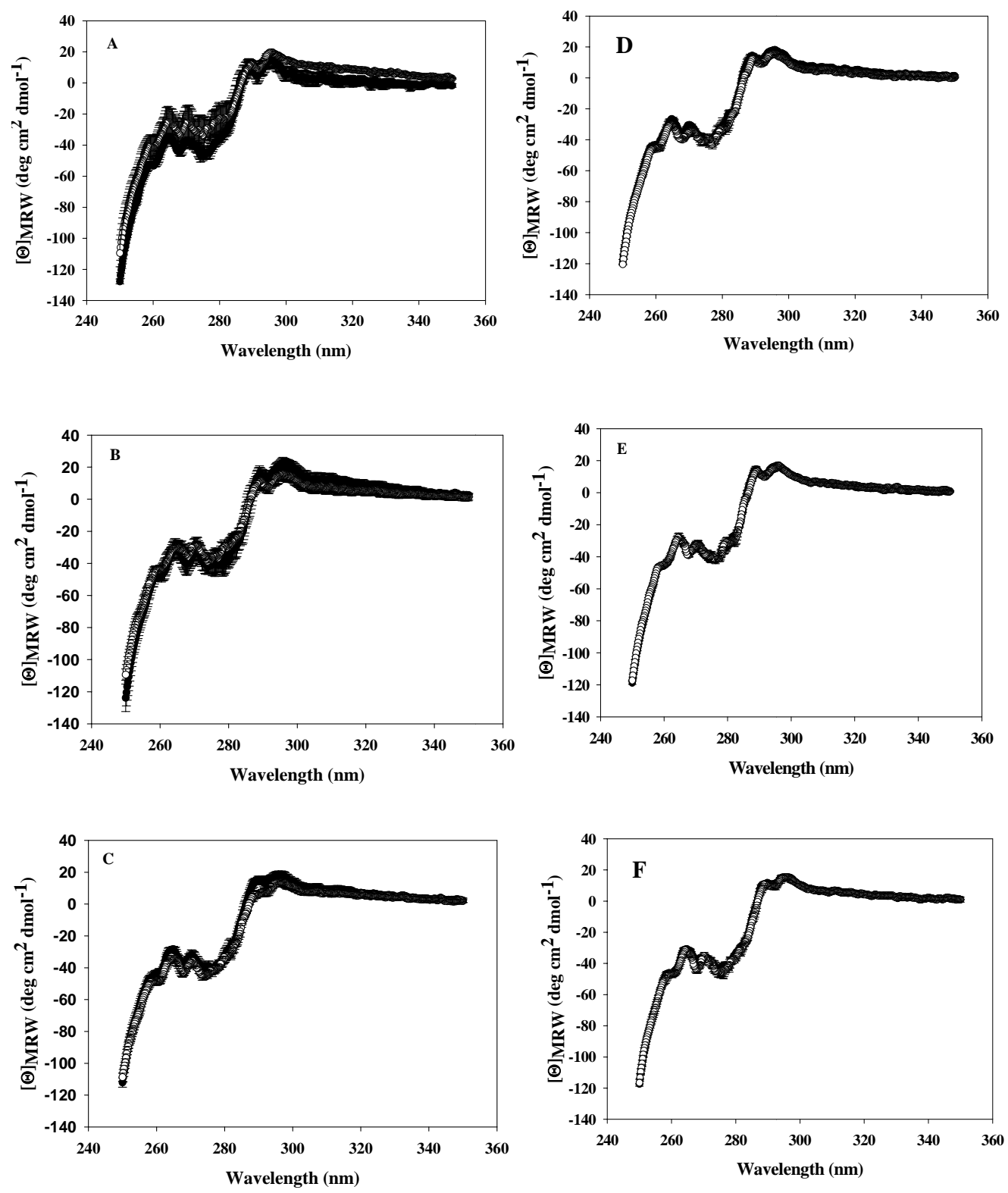

Figure 7. Average of Near UV CD spectra ( $\mathrm{n}=3$ ) of buffer subtracted 1 and $10 \mathrm{mg} / \mathrm{mL}$, anti streptavidin in $10 \mathrm{mM}$ sodium acetate $\mathrm{pH} 3.5$ (Graphs A and D), $10 \mathrm{mM}$ sodium acetate $\mathrm{pH} 5.0$ (Graphs B and E), and $10 \mathrm{mM}$ sodium phosphate $\mathrm{pH} 8.0$ (Graphs C and F) compared to 60 minutes exposed material at the same $\mathrm{pH}$. Standard deviation used to generate the error bars. Graphs A to C represent $1 \mathrm{mg} / \mathrm{mL}$ anti-streptavidin at $\mathrm{pH}$ 3.5, 5.0, and 8.0, respectively. Graphs D to F represent $10 \mathrm{mg} / \mathrm{mL}$ anti-streptavidin at $\mathrm{pH}$ 3.5, 5.0, and 8.0, respectively. ( unexposed, o exposed). 
The effect of light exposure on the secondary structure of the protein was examined using both CD and FTIR spectroscopy. Interrogation of the secondary structure by Far UV CD shows distinct differences between the unexposed sample and samples exposed up to 60 minutes with $302 \mathrm{~nm}$ light (Figures 8 and 9). The differences observed in the secondary structure are related to both the $\mathrm{pH}$ of the protein solution and to the concentration of the protein. For all samples the structure is dominated by an intense negative band between $210-220 \mathrm{~nm}$ reflecting the $\beta$-sheet structure of anti-streptavidin. At $0.1 \mathrm{mg} / \mathrm{mL}$ several trends can be noted. There is a decrease in ellipticity in the region from $195-205 \mathrm{~nm}$ which suggests that there is an increase in random coil upon exposure to light. At $\mathrm{pH} 3.5$, the signal at 215-220 nm becomes more negative with increasing exposure time, while at $\mathrm{pH} 5$ and 8 the signal becomes more positive. At $1 \mathrm{mg} / \mathrm{mL}$ the pH 3.5 sample exposed for 60 minutes is dramatically different having a much more negative peak between $215 \mathrm{~nm}-220 \mathrm{~nm}$ which was similar to that observed for the $0.1 \mathrm{mg} / \mathrm{mL}$ time course experiment. The $\mathrm{pH} 5$ condition showed no change, while the $\mathrm{pH} 8$ sample also showed a decrease in the $215-220 \mathrm{~nm}$ signal. At the highest concentration of $10 \mathrm{mg} / \mathrm{mL}$, the trend once again shows the $\mathrm{pH} 3.5$ signal becoming more negative at 215-220 nm while the $\mathrm{pH} 5$ and 8 both show an increase in the same region. The changes in the negative band at 215-220 nm minimally indicate an alteration of the $\beta$-sheet structure with the trend to more positive values representing loss of $\beta$-sheet structure and a concomitant increase in random coil. Differences in the Far UV CD signals upon aggregation of light exposed anti-streptavidin may also be accounted for by absorption flattening. Absorption flattening occurs because of different light paths through the sample solution upon uneven distribution of chromophores such as typically observed during aggregation. $^{54,55}$ 

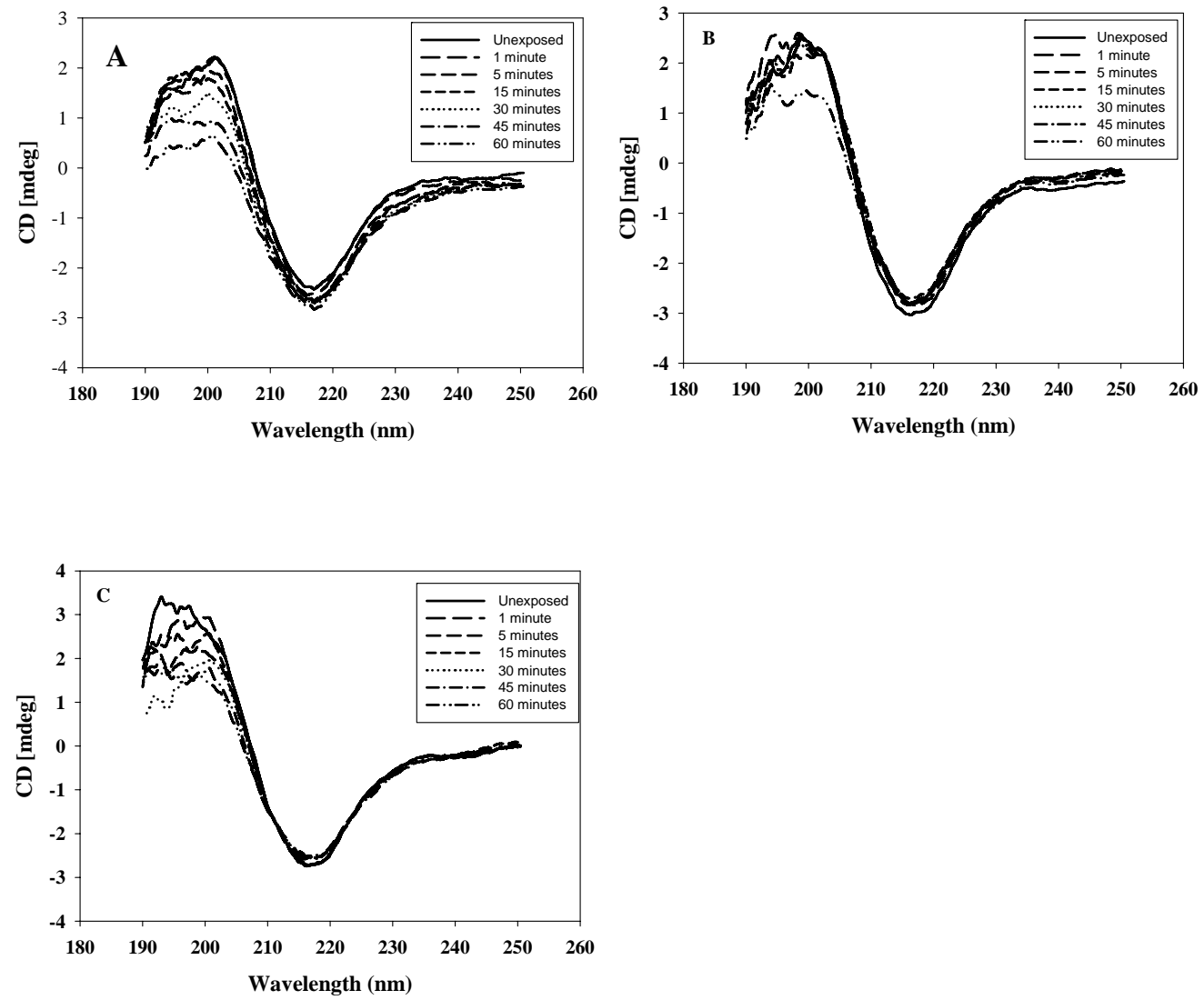

Figure 8. Far UV CD of buffer subtracted $0.1 \mathrm{mg} / \mathrm{mL}$ anti streptavidin in $10 \mathrm{mM}$ sodium acetate pH 3.5 (Graph A), 10mM sodium acetate pH 5.0 (Graph B), and 10mM sodium phosphate pH 8.0 (Graph C) with increasing exposure times of $0,1,5,15,30,45,60$ minutes. 

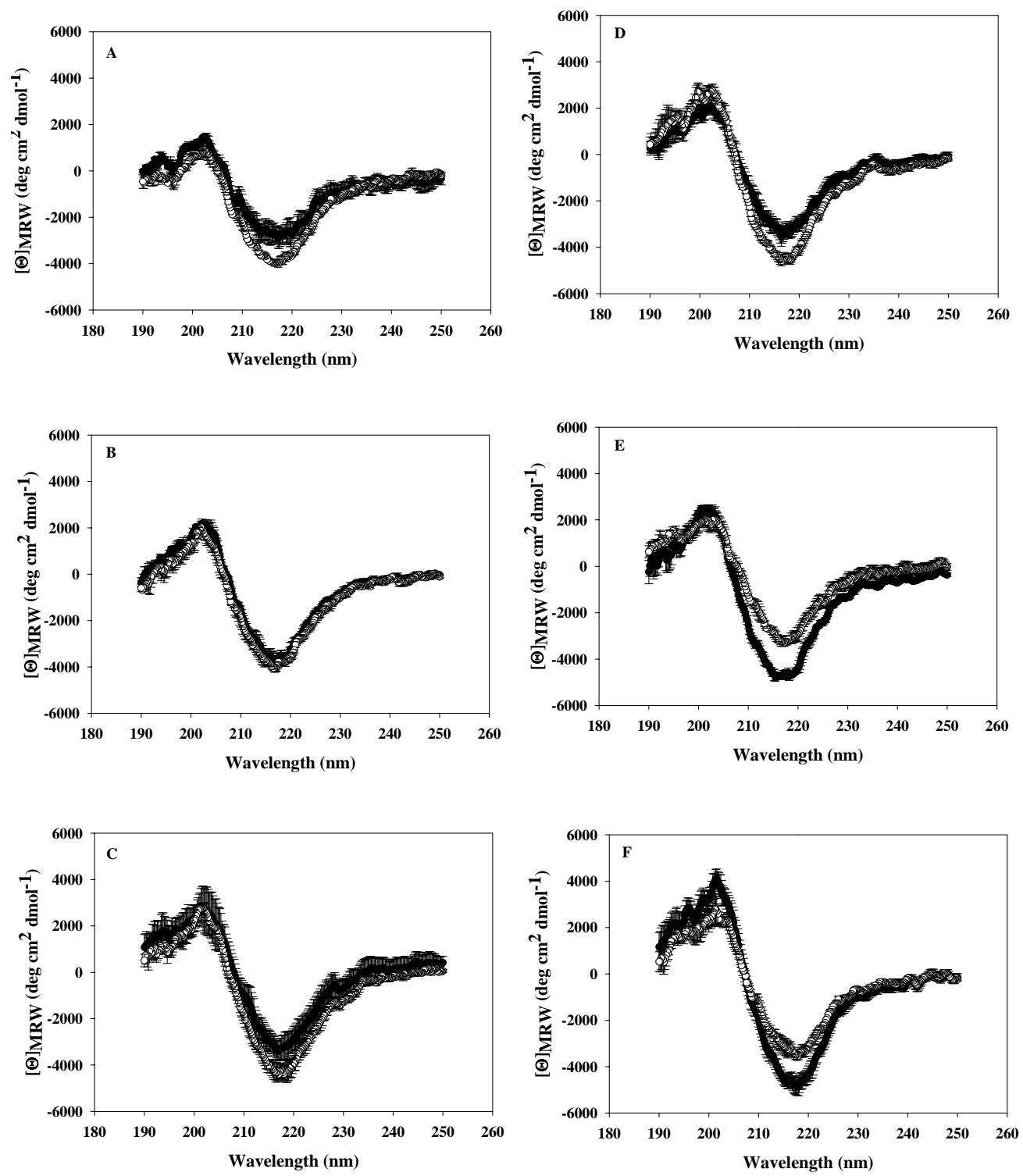

Figure 9. Average of Far UV CD spectra ( $\mathrm{n}=3$ ) of buffer subtracted 1 and $10 \mathrm{mg} / \mathrm{mL}$, anti streptavidin in $10 \mathrm{mM}$ sodium acetate $\mathrm{pH} 3.5$ (Graphs A and D), $10 \mathrm{mM}$ sodium acetate $\mathrm{pH} 5.0$ (Graphs B and E), and $10 \mathrm{mM}$ sodium phosphate $\mathrm{pH} 8.0$ (Graphs C and F) compared to 60 minutes exposed material at the same $\mathrm{pH}$. Standard deviation used to generate the error bars. Graphs A to C represent $1 \mathrm{mg} / \mathrm{mL}$ anti-streptavidin at $\mathrm{pH}$ 3.5, 5.0, and 8.0, respectively. Graphs D to F represent $10 \mathrm{mg} / \mathrm{mL}$ anti-streptavidin at $\mathrm{pH}$ 3.5, 5.0, and 8.0, respectively. (• unexposed, o exposed). 
Examination of the amide I region of the FT-IR spectrum using second derivative analysis shows that the anti-streptavidin spectrum is dominated by bands at approximately 1690 and $1639 \mathrm{~cm}^{-1}$ frequently associated with $\beta$-sheet structure. ${ }^{50,56}$ The FT-IR spectra were collected for both the $1 \mathrm{mg} / \mathrm{mL}$ and $10 \mathrm{mg} / \mathrm{mL}$ samples, though for simplicity of discussion, only the $10 \mathrm{mg} / \mathrm{mL}$ data is shown here (Figure 10). No concentration effect was observed. In general, there are a number of additional bands between 1660 to $1680 \mathrm{~cm}^{-1}$. These bands have been assigned to turns in the secondary structure. ${ }^{50,56}$ One additional band is observed at approximately $1615 \mathrm{~cm}^{-1}$ and is considered to be associated with intermolecular $\beta$-sheet structure structures. Interestingly, FTIR analysis for the $10 \mathrm{mg} / \mathrm{mL}$ anti streptavidin in $10 \mathrm{mM}$ sodium acetate, $\mathrm{pH} 3.5$ showed the most dramatic difference upon exposure for 60 minutes at 302nm, primarily in the region of 1660 to $1680 \mathrm{~cm}^{-1}$ where the structure is dominated by turns.

However, there is also some difference in the signal at $1615 \mathrm{~cm}^{-1}$. The anti streptavidin in $10 \mathrm{mM}$ sodium phosphate $\mathrm{pH} 8.0$ showed very little difference in the secondary structure while the $\mathrm{pH}$ 5.0 sample showed only small changes in the spectrum making a definitive assessment difficult. 

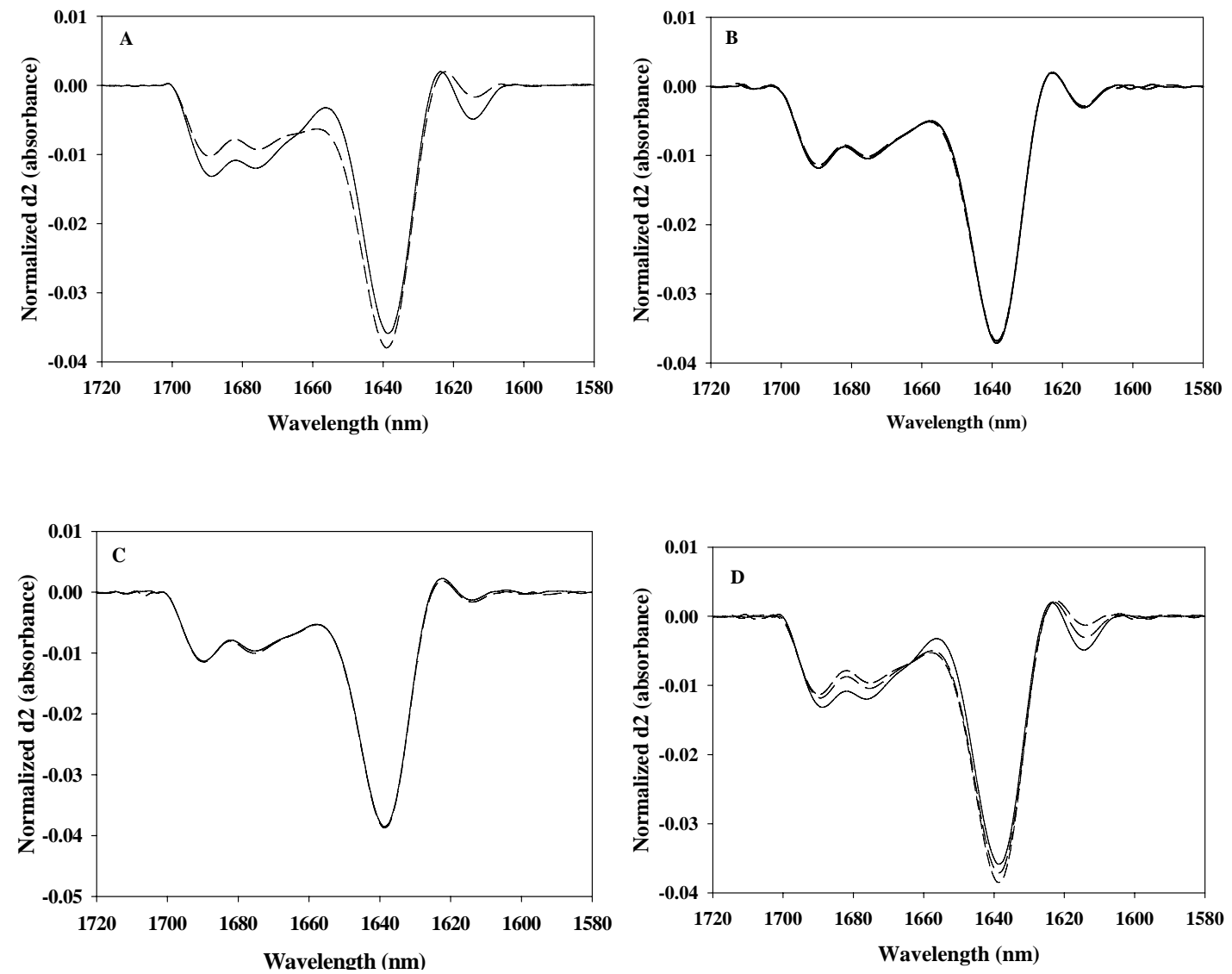

Figure 10. FTIR of $10 \mathrm{mg} / \mathrm{mL}$ of anti streptavidin in $10 \mathrm{mM}$ sodium acetate $\mathrm{pH} 3.5$ (Graph A), 10 mM sodium acetate pH 5.0 (Graph B), 10 mM sodium phosphate $\mathrm{pH} 8.0$ (Graph C) exposed to 302nm light from 0, 15, and 30 minutes. (— unexposed, - - exposed). Comparison of FTIR of $10 \mathrm{mg} / \mathrm{mL}$ of anti streptavidin in $10 \mathrm{mM}$ sodium acetate $\mathrm{pH} 3.5$ and 5.0 and $10 \mathrm{mM}$ sodium phosphate $\mathrm{pH} 8.0$ is shown in the lower right panel Graph D. Data obtained using a Bruker FTIR. (- $\mathrm{pH} 3.5,--\mathrm{pH}$ 5.0, - - - pH 8.0). 


\section{Ellman's Test for free sulfhydryl groups}

A simple Ellman's test for free sulfhydryl groups showed that the starting, unexposed material contained little to no free sulfhydryl groups (data not shown). After exposure to $302 \mathrm{~nm}$ light, the free sulfhydryl content of the samples remained below the limit of detection.

\section{Discussion:}

In the studies presented here we examined the effects of $\mathrm{pH}$ and protein concentration on the stability of an IgG1 mAb following exposure to UV light at a wavelength representative to what may be experienced during the purification process. We examined three separate $\mathrm{pH}$ conditions, $\mathrm{pH}$ 3.5, 5.0 and 8.0, at three separate antibody concentrations ranging from dilute solutions of $0.1 \mathrm{mg} / \mathrm{mL}$ to $10 \mathrm{mg} / \mathrm{mL}$. These solutions were exposed to $302 \mathrm{~nm}$ light for up to 60 minutes and then analyzed by a variety of techniques monitoring physical and conformational stability. Based on size exclusion HPLC and SDS-PAGE data we conclude that there is a pH and concentration dependence on the rate of aggregation upon light exposure. The amount of aggregation increased with increasing $\mathrm{pH}$. Interestingly, non-reducible aggregates were observed upon exposure to $302 \mathrm{~nm}$ light. A pH dependence was observed where $\mathrm{pH} 8.0$ showed the greatest extent of non-reducible aggregates, the trend being $\mathrm{pH} 3.5<\mathrm{pH} 5.0<\mathrm{pH} 8.0$. Examination of the thermal properties of these solutions showed that the apparent melting transitions decreased with decreasing $\mathrm{pH}$. At all three $\mathrm{pH}$ values studied, the apparent melting transitions became broader upon light exposure, with the lowest temperatures being observed for the lowest $\mathrm{pH}$. In contrast to the trend for aggregation, the conformational stability revealed the greatest changes in the secondary structure at $\mathrm{pH} 3.5$ upon light exposure and followed the trend of $\mathrm{pH} 3.5>\mathrm{pH} 5.0>\mathrm{pH} 8.0$.

As noted above, upon exposure to light at $302 \mathrm{~nm}$, anti streptavidin experienced a number of negative consequences. Predominately, the formation of aggregates is both time and $\mathrm{pH}$ 
dependent. Perhaps not surprisingly, the longer the UV-exposure, the more aggregates are observed. This trend of increasing aggregation upon increasing exposure times to UV light has been well documented by others. ${ }^{38,39,43}$ As mentioned, anti streptavidin forms predominately soluble non-reducible aggregates under conditions studied here. This is in contrast to the observations made with sTNF-R1. ${ }^{24}$ Like anti-streptavidin, sTNF-R1 predominately has a $\beta$ sheet structure and contains a large number of disulfide bonds. However, unlike antistreptavidin, sTNF-R1 showed primarily reducible aggregation upon exposure to 302nm light. Roy et. al. reported that sTNF-R1, under similar conditions, underwent tryptophan-mediated formation of intermolecular disulfide cross links. ${ }^{39}$ Anti-streptavidin appears to form covalently linked, non-reducible aggregates and therefore its aggregation must proceed through a different mechanism.

Recently, Mozzacionacci et. al. demonstrated that exposure to $254 \mathrm{~nm}$ light lead to the formation of dithiohemiacetal and thioether cross-links. ${ }^{33}$ Such products are potential candidates also for our experimental conditions (302 nm light) but must await further characterization. While this has yet to be demonstrated as the pathway that anti-streptavidin is following, it seems likely that this is the case given the non-reducible nature of the aggregates produced by exposure of anti-streptavidin to $302 \mathrm{~nm}$ light. The negative test for free sulfhydryls would lend support to this mechanism.

\section{Effect of light on conformation of the anti-streptavidin $m A b$}

To understand the impact of light exposure on anti-streptavidin and help define the mechanism behind the $\mathrm{pH}$ dependence of the observed aggregation we studied the conformation of the mAb before and after exposure to $302 \mathrm{~nm}$ light. One of the first experiments conducted was to examine the thermal stability of anti-streptavidin before and after exposure to $302 \mathrm{~nm}$ 
light. DSC is typically used to monitor the heat effects upon alteration in non-covalent interactions in proteins. ${ }^{25}$ We also monitored the environment of the tryptophan residues by intrinsic fluorescence as a function of temperature. From the data, it is apparent that the $\mathrm{pH}$ impacts the thermal stability of anti-streptavidin. As the $\mathrm{pH}$ decreased, so did the apparent $\mathrm{T}_{\mathrm{m}}$. The decrease in apparent $T_{m}$ values has been observed previously ${ }^{53}$ and has been attributed to the protonation of the amino acid side chains resulting in a reduction of $\beta$-sheet content and structural changes in the $\mathrm{F}_{\mathrm{c}}$ and $\mathrm{F}_{\mathrm{ab}}$ fragments. ${ }^{57}$ A simple interpretation of the reduction in $\mathrm{T}_{\mathrm{m}}$ is that it indicates a lower thermodynamic stability of the protein. ${ }^{53}$ Minimally, the $\mathrm{T}_{\mathrm{m}}$ decreases because it requires less energy to unfold the antibody. The fact that the $\mathrm{T}_{\mathrm{m}}$ is lower at $\mathrm{pH} 3.5$ than at $\mathrm{pH} 8.0$ suggests that the lower the $\mathrm{pH}$, the less stable anti-streptavidin would be and the more aggregation we would expect. This is in direct conflict with the observation that as the $\mathrm{pH}$ is raised, the amount of high molecular weight species increases. Thermal unfolding by monitoring changes in tryptophan fluorescence was also used to study the stability of the photodegraded $\mathrm{mAb}$. The monitoring of the environment surrounding the remaining intact tryptophans by their intrinsic fluorescence showed a red shift, indicating more solvent exposed tryptophan residues, in the $\mathrm{F}_{\max }$ upon heating the solution which reached a plateau past the $\mathrm{T}_{\mathrm{m}}$. This method yielded overall apparent $\mathrm{T}_{\mathrm{m}}$ values for the unexposed material that were in good agreement with the DSC data. Similar to what was observed by DSC, the apparent $\mathrm{T}_{\mathrm{m}}$ decreased with increasing $\mathrm{pH}$, which is again in direct contrast to the trends for aggregation. This trend based on $\mathrm{pH}$ suggests that the aggregation is not tied to the thermodynamic stability of the protein

One possible explanation for this trend is based on the overall charge of the mAb at the lower $\mathrm{pH}$. The measured $\mathrm{pI}$ of the protein is 8.7 and would be expected to have a much greater 
degree of positive charge at the lower $\mathrm{pH}$ resulting in charge repulsion and a concomitant decrease in aggregation. It has been reported that as the amino acid side chains become protonated, it forces the antibody to reorganize into a new structure, the A-state. This so called A-state has been reported to be relatively compact and as a result has been ascribed as the reason for less aggregation than expected in IgG heated samples at low $\mathrm{pH}^{57}$

Besides the impact of $\mathrm{pH}$ on the apparent melting transitions, light exposure induced significant changes as well. For the three $\mathrm{pH}$ conditions studied, a decrease in the largest transition peak, as observed by DSC, which is typically assigned to the Fab domain, was observed after light exposure. Differences in the other transitions aren’t as easily discernible, but in all cases, even after 30 minutes of exposure, the final transition, typically assigned to the $\mathrm{CH} 3$ domain can be readily seen. Broadening of the transitions upon light exposure is most readily seen at the higher $\mathrm{pH}$ 's of 5.0 and 8.0. Similar to our observations, it has previously been reported that light exposure in the range of $310 \mathrm{~nm}$ to $700 \mathrm{~nm}$ of an IgG1 antibody at pH 7.2 can induce broadening of the unfolding peaks and has been attributed to a loss of structural cooperativity. ${ }^{25}$

Interestingly, from the intrinsic fluorescence data, it is again clear that exposure to UV light has a profound impact on the thermal stability of anti-streptavidin. Changes in the $F_{\max }$ were observed at as low as $30^{\circ} \mathrm{C}$ for the $\mathrm{pH} 3.5$ exposed samples and at $40^{\circ} \mathrm{C}$ for the $\mathrm{pH} 5.0$ and 8.0 exposed samples. The deviations from baseline suggest thermal instability at a much lower temperature than for the native protein. In simple terms, this indicates that the remaining intact tryptohans reside in a variety of microenvironments, some of which have become more solvent exposed at lower temperatures. Again this is in contrast to the relationship between aggregation and $\mathrm{pH}$, where the higher $\mathrm{pH}$ becomes more strongly aggregated. Minimally, at lower $\mathrm{pH}$ values 
there is a change in the structure of anti-streptavidin which reduces the formation of aggregates, in agreement with the DSC data. From the sequence of anti-streptavidin, it can be noted that there are a total of 26 tryptophans, with only six being found widely dispersed throughout the two light chains. The remaining 20 tryptophans can be found in the two heavy chains with a preponderance located in the Fab region of the antibody. The shift in $\mathrm{F}_{\max }$ upon heating as observed by intrinsic fluorescence measurements would suggest that changes in the structure, likely the Fab, are occurring upon light exposure. While the overall charge of anti-streptavidin is positive at $\mathrm{pH}$ 3.5, as the $\mathrm{pH}$ is raised anti streptavidin becomes less and less positively charged allowing it to become more and more susceptible to aggregation upon light exposure. Above the $\mathrm{pK}_{\mathrm{a}}$ of histidine, 6.0, the imidazole side chain becomes deprotonated further reducing the overall positive charge and making anti streptavidin closer to neutrally charged, which might also explain the difference between the extent of aggregation at $\mathrm{pH} 5$ and $\mathrm{pH} 8$.

In direct contrast to what we observed for anti-streptavidin, the tertiary structural analysis of sTNF-R1 exposed to $302 \mathrm{~nm}$ light showed changes in the positioning of the tryptophan and phenylalanine residues in asymmetric environments. ${ }^{39}$ For anti-streptavidin exposed to light, a close examination of the tertiary structure by near UV CD as well as $2^{\text {nd }}$ derivative UV-vis spectroscopy and intrinsic tryptophan fluorescence at $25^{\circ} \mathrm{C}$ failed to detect significant differences at $\mathrm{pH} 5$ and 8 upon exposure under the conditions described above. At pH 3.5, there may be a small difference for the $1 \mathrm{mg} / \mathrm{mL}$ sample as observed by near UV CD. Near UV CD and $2^{\text {nd }}$ derivative UV-vis spectra are influenced by the microenvironment of the aromatic residues and disulfides within the antibody, so the lack of changes observed by these techniques is suggestive that the tertiary structure is intact at $\mathrm{pH} 5$ and $8 .{ }^{58}$ 
In agreement with the near UV CD and $2^{\text {nd }}$ derivative UV-vis data, the intrinsic tryptophan fluorescence at $25{ }^{\circ} \mathrm{C}$ also failed to detect a peak shift whether it was a blue shift or red shift, again suggesting that the tertiary structure, at least around the tryptophan residues remained intact. However, the data showed in all cases a decrease in fluorescence intensity upon light exposure. In this case, since excitation was accomplished at $295 \mathrm{~nm}$, the predominate residues probed were again the 26 tryptophan residues in anti-streptavidin. The decrease in fluorescence intensity upon exposure may simply be a result of the destruction of tryptophan residues upon exposure to $302 \mathrm{~nm}$ light reducing the overall quantum yield observed. ${ }^{59}$ Interestingly, a fluorescence test for the presence of $\mathrm{N}$-formylkynurenine (excitation at 315nm followed by emission scan at 440-450nm $)^{39}$ was negative as was a fluorescence test for dityrosine $^{60}$ (data not shown). This is in contrast to sTNF-R1, which formed Nformylkynurenine upon exposure to 302nm light, implicating its sole tryptophan in the degradation process. ${ }^{39}$ Further work will need to be conducted to elucidate the exact cause for the decrease in the peak intensity upon exposure.

Far UV CD and FT-IR were used to study the impact of light exposure on the secondary structure of anti-streptavidin under the conditions described above. Both methods showed the most dramatic differences for the pH 3.5 samples. Upon exposure the far UV-CD pH 3.5 spectra showed distinct differences around the wavelength of $197 \mathrm{~nm}$ suggesting that there is a change in the extent of random coil upon exposure to light. As pointed out earlier, the structure for all of the samples is dominated by an intensely negative band between $210-220 \mathrm{~nm}$, reflecting the $\beta$ sheet structure of anti-streptavidin. For all pH’s at all three concentrations there are slight differences observed between the exposed and the unexposed sample in the negative band at 210-220 nm which may indicate a change in the $\beta$-sheet structure. In good agreement with the 
far-UV CD data, FT-IR shows the predominate structure of anti-streptavidin to be $\beta$-sheet. The anti-streptavidin FT-IR spectrum is dominated by bands at approximately 1690 and $1639 \mathrm{~cm}^{-1}$ which are often associated with $\beta$-sheet structure. No concentration effect was observed. There are also a number of additional bands from 1660 to $1680 \mathrm{~cm}^{-1}$ which have been assigned to turns in the secondary structure. One final band should be mentioned as well. It is observed at approximately $1615 \mathrm{~cm}^{-1}$ and is considered to be associated with intermolecular $\beta$-sheet structure structures. Interestingly, FTIR analysis for the $10 \mathrm{mg} / \mathrm{mL}$ anti streptavidin in $10 \mathrm{mM}$ sodium acetate, pH 3.5 showed the most dramatic difference upon exposure for 60 minutes at $302 \mathrm{~nm}$, primarily in the region of 1660 to $1680 \mathrm{~cm}^{-1}$ where the structure is dominated by turns. However, there is also some difference in the signal at $1615 \mathrm{~cm}^{-1}$. The anti-streptavidin in 10 $\mathrm{mM}$ sodium phosphate $\mathrm{pH} 8.0$ showed very little difference in the secondary structure. The $\mathrm{pH}$ 5.0 sample showed only small changes in the spectrum making a definitive assessment difficult.

\section{Conclusions:}

From this work, it is once again very apparent that care must be exercised to protect monoclonal antibodies from light. The amount of time for exposure to $302 \mathrm{~nm}$ to effect noticeable changes in anti-streptavidin was as little as 1 minute. In contrast to sTNF-R1, antistreptavidin formed non-reducible covalently linked oligomers, mostly in the form of dimer and trimer along with higher order species. The following $\mathrm{pH}$ dependence in the rate of aggregation was observed: $\mathrm{pH} 3.5<\mathrm{pH} 5.0<\mathrm{pH}$ 8.0. One potential explanation may be the formation of dithiohemiacetal and thioether cross-links. ${ }^{33}$ Further work will need to be conducted to elucidate the mechanism.

Exposure of anti-streptavidin to $302 \mathrm{~nm}$ light resulted in changes to the apparent melting transitions as observed by DSC and thermal unfolding as monitored by intrinsic fluorescence. Here the following trend was observed: $\mathrm{pH} 3.5>\mathrm{pH} 5.0>\mathrm{pH}$ 8.0. One explanation for this 
trend might be that as the amino acid side chains become progressively more protonated, the antibody is forced to reorganize into a new structure, the A-state which is relatively compact and reduces the potential for aggregation. ${ }^{57}$ The tertiary structure of anti-streptavidin appeared to remain intact, but analysis of the secondary structure revealed changes in the $\beta$-sheet structure with the following trend: $\mathrm{pH} 3.5>\mathrm{pH} 5.0>\mathrm{pH}$ 8.0.

\section{Future Directions:}

A number of different experiments would help further the current work. A better understanding of the role that $\mathrm{mAb}$ conformation plays on the rate of aggregate formation upon light exposure would be beneficial. The thermal unfolding and secondary structural changes upon light exposure followed the trend of $\mathrm{pH} 3.5>\mathrm{pH} 5.0>\mathrm{pH}$ 8.0, while the rate of aggregation had the opposite trend of $\mathrm{pH} 3.5<\mathrm{pH} 5.0<\mathrm{pH}$ 8.0. Perhaps ANS fluorescence binding experiments would show the degree of surface exposure of hydrophobic groups. H/D exchange with FTIR detection may help with elucidating changes in the secondary structure at the different pH's upon light exposure. There are also several experiments that would help in understanding the type of chemical modifications that occur during anti-streptavidin's exposure to 302nm light. The simplest would be ion exchange chromatography, either anion or cation which would reveal differences in the overall charge of the exposed antibody from degradation such as deamidation and oxidation. Short exposure times to 302nm light of 1-5 minutes may show differences between the unexposed anti-streptavidin and the exposed sample. Peptide mapping would help provide information on the chemical modification that lead to the formation of the aggregates observed. A typical peptide mapping experiment would first involve the reduction of any disulfide bonds with dithiothreitol (DTT) under denaturing conditions to help ensure complete carboxymethylation. Subsequent digestion of anti-streptavidin with trypsin would theoretically yield 53 peptide fragments of sufficient size to allow for standard analysis, 
which is generally accomplished by reverse phase HPLC and mass spectroscopy detection. This experiment would allow for the detection of chemical modifications and provide information that either supports or contradicts the proposed mechanism of aggregation. Once the chemical modification sites are known, mutants eliminating those amino acid residues susceptible to degradation could be made to help confirm the mechanism and to aid in better understanding the role that conformation and $\mathrm{pH}$ play in the photodegradation process.

It would also be interesting to see the impact that light exposure has to the long term stability of anti-streptavidin. Does the formation of aggregates by light exposure lead to an increased rate of aggregation or does the formation simply raise the baseline amount of aggregation? Common stability indicating assays such as size exclusion HPLC, cation exchange HPLC, and peptide mapping would allow for the rate of aggregation and chemical modifications to be monitored over a series of time points.

The current work was conducted using the IgG1 variant of anti-streptavidin. Although it has close sequence homology with the IgG2 variant, there are distinct differences between the two versions, particularly in the hinge region involving the disulfide structure. The major difference between the subclasses arise from serine to cysteine substitutions in the hinge region and the flexible loop of the heavy chain of IgG2 molecules. ${ }^{61}$ This allows for a variety of isoforms for the IgG2 molecule which have different disulfide links. It would be interesting to duplicate this work using the IgG2 variant. Would the specific variants have different susceptibilities to photodegradation. Would the same trends observed for the IgG1 hold for the IgG2 subclass? 


\section{References:}

1 Kerwin, B. A. \& Richard L. Remmele, J. Protect from Light: Photodegradation and Protein Biologics. Journal of Pharmaceutical Sciences 96, 1468-1479 (2007).

2 Frank, J., JZN, Braat, A. \& Duine, J. A. Assessment of Protein Purity by Chromatography and Multiwavelength Detection. Analytical Biochemistry 162, 65-73 (1987).

3 Lloyd-Williams, P., Albercio, F. \& Giralt, E. Convergent solid-phase peptide synthesis VII. Synthesis, using a photolabile resin, and purification of a methionine-containing protected peptide. International Journal of Peptide Research 37, 58-60 (1991).

4 Klein, R. S., Werth, V. P., Dowdy, J. C. \& Sayre, R. M. Analysis of Compact Fluorescent Lights for Use by Patients with Photosensitive Conditions. Photochemistry and Photobiology 85, 1004-1010 (2009).

5 Sayre, R. M., Dowdy, J. C. \& Poh-Fitzpatrick, M. Dematological Risk of Indoor Ultraviolet Exposure from Contemporary Lighting Sources. Photochemistry and Photobiology 80, 47-51 (2004).

6 Cromwell, M. E. M., Hilario, E. \& Jacobson, F. Protein Aggregation and Bioprocessing. The AAPS Journal 8, E572-E579 (2006).

7 Shire, S. Formulation and manufacturability of biologics. Current Opinion in Biotechnology 20, 708-714 (2009).

8 Zhou, J. X., Tressel, T., Yang, X. \& Seewoester, T. Implementation of advanced technologies in commercial monoclonal antibody production. Biotechnology 3, 11851200 (2008).

9 Singh, S. K. Impact of Product-Related Factors on Immunogenicity of Biotherapeutics. Journal of Pharmaceutical Sciences 100, 354-387 (2011).

10 Frokjaer, S. \& Otzen, D. E. Protein Drug Stability: A Formulation Challenge. Nature Reviews Drug Discovery 4, 298-306 (2005).

11 Rathore, N. \& Rajan, R. S. Current Perspectives on Stability of Protein Drug Products during Formulation, Fill and Finish Operations. Biotechnology Progress 24, 504-514 (2008).

12 Cholewinski, M., Lückel, B. \& Horn, H. Degradation pathways, analytical characterization and formulation strategies of a peptide and a protein Calcitonine and human growth hormone in comparison. Pharmaceutica Acta Helvetiae 71, 405-419 (1996).

13 Wang, W., Singh, S., Zeng, D. L., King, K. \& Nema, S. Antibody Structure, Instability, and Formulation. Journal of Pharmaceutical Sciences 96, 1-26 (2007).

14 Chi, E. Y., Krishnan, S., Randolph, T. W. \& Carpenter, J. F. Physical Stability of Proteins in Aqueous Solution: Mechanism and Driving Forces in Nonnative Protein Aggregation. Pharmaceutical Research 20, 1325-1336 (2003).

15 Manning, M. C., Patel, K. \& Borchardt, R. T. Stability of Protein Pharmaceuticals. Pharmaceutical Research 6, 903-918 (1989).

16 Manning, M. C., Chou, D. K., Murphy, B., Payne, R. W. \& Katayama, D. S. Stability of Protein Pharmaceuticals: An Update. Pharmaceutical Research 27, 544-575 (2010).

17 Zheng, K., Middaugh, C. R. \& Siahaan, T. J. Evaluation of Physical Stability of the EC5 Domain of E-Cadherin: Effects of $\mathrm{pH}$, Temperature, Ionic Strength, and Disulfide Bonds. Journal of Pharmaceutical Sciences 98, 63-73 (2009). 
18 Philo, J. S. \& Arakawa, T. Mechanisms of Protein Aggregation. Current Pharmaceutical Biotechnology 10, 348-351 (2009).

19 Hawe, A. \& Frieß, W. Formulation Development for Hydrophobic Therapeutic Proteins. Pharmaceutical Development and Technology 12, 223-237 (2007).

20 Cleland, J. L., Powell, M. F. \& Shire, S. J. The Development of Stable Protein Formulations: A Close Look at Protein Aggregation, Deamidation, and Oxidation. Critical Reviews in Therapeutic Drug Carrier Systems 10, 307-377 (1993).

21 Fradkin, A. H., Carpenter, J. F. \& Randolph, T. W. Immunogenicity of Aggregates of Recombinant Human Growth Hormone in Mouse Models. Journal of Pharmaceutical Sciences 98, 3247-3264 (2009).

22 Ohkuri, T. et al. A Protein's Conformational Stability Is an Immunologically Dominant Factor: Evidence That Free-Energy Barriers for Protein Unfolding Limit the Immunogenicity of Foreign Proteins. The Journal of Immunology 185, 4199-4205 (2010).

23 Davies, M. J. Singlet Oxygen-Mediated Damage to Proteins and its Consequences. Biochemical and Biophysical Research Communications 305, 761-770 (2003).

24 Davies, M. J. T. \& R.J.W. Photo-oxidation of proteins and its role in cataractogenesis. Journal of Photochemistry and Photobiology B: Biology 63, 114-125 (2001).

25 Maity, H., O'Dell, C., Srivastava, A. \& Goldstein, J. Effects of Arginine on Photostability and Thermal Stability of IgG1 Monoclonal Antibodies. Currrent Pharmaceutical Biotechnology 10, 761-766 (2009).

26 Jiang, J., Abraavicius, D., Bulheller, B. M., Hirst, H. D. \& Mukamel, S. Ultraviolet Spectroscopy of Protein Backbone Transitions in Aqueous Solutions: Combined QM and MM Simulations. Journal of Physical Chemistry, B 114, 8270-8277 (2010).

27 Bent, D. V. \& Hayon, E. Excited State Chemistry of Aromatic Amino Acids and Related Peptides. III. Tryptophan. Journal of the American Chemical Society 97, 2612-2619 (1975).

28 Creed, D. The Photophysics and photochemistry of the near UV absorbing amino-acids 1. Tryptophan and its simple derivatives. Photochemistry and Photobiology 39, 537-562 (1984).

29 Becker, D., Swarts, S., Champagne, M. \& Sevilla, M. D. An ESR investigation of the reaction of glutathione, cysteine and penicillamine thiyl radicals: competitive formation of RSO', R', RSSR'; and RSS· International Journal of Radiation Biology 53, 767-786 (1988).

30 Everett, S. A., Schöneich, C., Stewart, J. H. \& Asmus, K.-D. Perthiyl Radicals, Trisulfide Radical Ions, and Sulfate Formation. A CombinedPhotolysis and Radiolysis Study on Redox Processes with Organic Di- and Trisulfides. The Journal of Physical Chemistry 96, 306-314 (1992).

31 Mozziconacci, O., Sharov, V., Williams, T. D., Kerwin, B. A. \& Schöneich, C. Peptide Cysteine Thiyl Radicals Abstract Hydrogen Atoms from Surrounding Amino Acids: The Photolysis of a Cystine Containing Model Peptide. Journal of Physical Chemistry B 112, 9250-9257 (2008).

32 Vanhooren, A., Devreese, B., Vanhee, K., Beeumen, J. V. \& Hanssens, I. Photoexcitation of Tryptophan Groups Induces Reduction of Two Disulfide Bonds in Goat $\alpha$ Lactalbumin. Biochemistry 41, 11035-11043 (2002). 
33 Mozziconacci, O., Kerwin, B. A. \& Schöneich, C. Exposure of a Monoclonal Antibody, IgG1, to UV-Light Leads to Protein Dithiohemiacetal and Thioether Cross-Links: A Role for Thiyl Radicals? Chem. Res. Toxicol. 23, 1310-1312 (2010).

34 Mozziconacci, O., Kerwin, B. A. \& Schöneich, C. Photolysis of an Intrachain Peptide Disulfide Bond: Primary and Secondary Processes, Formation of $\mathrm{H}_{2} \mathrm{~S}$, and Hydrogen Transfer Reactions. Journal of Physical Chemistry, B 114, 3668-3688 (2010).

35 Mozziconacci, O., Kerwin, B. A. \& Schöneich, C. Reversible Hydrogen Transfer between Cysteine Thiyl Radical and Glycine and Alanine in Model Peptides: Covalent H/D Exchange, Radical-Radical Reactions, and L- to D-Ala Conversion. Journal of Physical Chemistry, B 114, 6751-6762 (2010).

36 Mozziconacci, O., Williams, T. D., Kerwin, B. A. \& Schöneich, C. Reversible Intramolecular Hydrogen Transfer between Protein Cysteine Thiyl Radicals and ${ }^{\alpha} \mathrm{C}-\mathrm{H}$ Bonds in Insulin: Control of Selectivity by Secondary Structure. Journal of Physical Chemistry, B 112 (2008).

37 Schöneich, C. Mechanisms of Protein Damage Induced by Cysteine Thiyl Radical Formation. Chem. Res. Toxicol. 21, 1175-1179 (2008).

38 Qi, P. et al. Characterization of the photodegradation of a human IgG1 monoclonal antibody formulated as a high-concentrated liquid dosage form. Journal of Pharmaceutical Sciences 98, 3117-3130 (2009).

39 Roy, S. et al. Light-Induced Aggregation of Type I Soluble Tumor Necrosis Factor Receptor. Journal of Pharmaceutical Sciences 98, 3182-3199 (2009).

40 Duenas, E. T., Keck, R., DeVos, A., Jones, A. J. S. \& Cleland, J. L. Comparison between Light Induced and Chemically Induced Oxidation of rhVEGF. Pharmaceutical Research 18, 1455-1460 (2001).

41 Lam, X., Yang, J. Y. \& Cleland, J. L. Antioxidants for Prevention of Methionine Oxidation in Recombinant Monoclonal Antibody HER2. Journal of Pharmaceutical Sciences 86, 1250-1255 (1997).

42 Liu, H., Gaza-Bulseco, G. \& Zhou, L. Mass Spectrometry Analysis of Photo-Induced Methionine Oxidation of a Recombinant Human Monoclonal Antibody. Journal of the American Society for Mass Spectrometry 20, 525-528 (2009).

43 Wei, Z. et al. Identification of a Single Tryptophan Residue as Critical for Binding Activity in a Humanized Monoclonal Antibody against Respiratory Syncytial Virus. Analytical Chemistry 79, 2897-2805 (2007).

44 Silvester, J. A. T., G.S.; Davies, M.J. Photodynamically Generated Bovine Serum Albumin Radicals: Evidence for Damage Transfer and Oxidation at Cysteine and Tryptophan Residues. Free Radical Biology \& Medicine 24, 754-766 (1998).

45 Vanhooren, A. et al. Selectivity of Tryptophan Residues in Mediating Photolysis of Disulfide Bridges in Goat $\alpha$-Lactalbumin. Biochemistry 45, 2085-2093 (2006).

46 Hatchard, C. G. \& Parker, C. A. A new sensitive chemical actinometer. II. Potassium ferrioxalate as a standard chemical actinometer. Proceedings of The Royal Society of London, Series A, Mathematical and Physical Sciences 235, 518-536 (1956).

47 Kuhn, H. J., Braslavsky, S. E. \& Schmidt, R. Chemical Actinometry. Pure and Applied Chemistry 76, 2105-2146 (2004).

48 Lucas, L. H. et al. Probing protein structure and dynamics by second-derivative ultraviolet absorption analysis of cation- $\pi$ interactions. Protein Sciences 15, 2228-2243 (2006). 
49 Dong, A. \& Caughey, W. S. Infrared Methods for Study of Hemoglobin Reactions and Structures. Methods in Enzymology 232, 139-175 (1994).

50 Dong, A., Huang, P. \& Caughey, W. S. Protein Secondary Structures in Water from Second-Derivative Amide I Infrared Spectra. Biochemistry 29, 3303-3308 (1990).

51 Dong, A., Jones, L. S., Kerwin, B. A., Krishnan, S. \& Carpenter, J. F. Secondary structures of proteins adsorbed onto aluminum hydroxide: Infrared spectroscopic analysis of proteins from low solution concentrations. Analytical Biochemistry 351, 282289 (2006).

52 Dong, A., Prestrelski, S. J., Allison, S. D. \& Carpentar, J. F. Infrared Spectroscopic Studies of Lyophilization- and Temperature-Induced Protein Aggregation. Journal of Pharmaceutical Sciences 84, 415-424 (1995).

53 Richard L. Remmele, J. in Analytical Techniques for Biopharmaceutical Development (eds Roberto Rodriguez-Diaz, Tim Wehr, \& Stephen Tuck) Ch. 13, 327-381 (Marcel Dekker, 2005).

54 Halling, P. Estimation of flattening coefficient for absorption and circular dichroism using simulation. Analytical Biochemistry 387, 76-81 (2009).

55 Castiglioni, E., Lebon, F., Longhi, G., Gangemi, R. \& Abbate, S. An Operative Approach to Correct CD Spectra Distortions due to Absorption Flattening. Chirality 20 (2008).

56 Pelton, J. T. \& McLean, L. R. Spectroscopic Methods for Analysis of Protein Secondary Structure. Analytical Biochemistry 277, 167-176 (2000).

57 Vermeer, A. W. P. \& Norde, W. The Thermal Stability of Immunoglobulin: Unfolding and Aggregation of a Multi-Domain Protein. Biophysical Journal 78, 394-404 (2000).

58 Vlasak, J. et al. Identification and characterization of asparagine deamidation in the light chain CDR1 of a humanized IgG1 antibody. Analytical Biochemistry 392, 145154 (2009).

59 Mach, H. et al. in Formulation and Delivery of Proteins and Peptides $<$ http://pubs.acs.org/isbn/9780841229594> Vol. 567 Ch. 5, 72-84 (ACS, 1994).

60 Malencik, D. A. \& Anderson, S. R. Dityrosine as a product of oxidative stress and fluorescent probe. Amino Acids 25, 233-247 (2003).

61 Dillon, T. M. et al. Structural and Functional Characterization of Disulfide Isoforms of the Human IgG2 Subclass. Journal of Biological Chemistry 283, 16206-16215 (2008). 